\title{
Microbial ecology of the South Atlantic Subtropical Gyre: a state-of-the-art review of an understudied ocean region
}

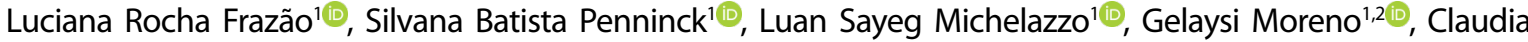

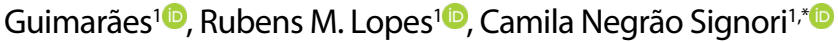 \\ 1 Departamento de Oceanografia Biológica, Instituto Oceanográfico, Universidade de São Paulo, Praça do Oceanográfico, 191. \\ 05508-120. São Paulo, Brazil \\ 2 Departamento de Física, Universidad de Moa, Avenida Calixto García Iñiguez \#15, entre Av. 7 de Diciembre y Calle Reynaldo Laffita \\ Rueda, Rpto, Caribe, Moa, Holguin, cp83330, Cuba \\ *Corresponding author: csignori@usp.br
}

\section{AbStRACt}

Understanding the dynamics of microbial plankton communities, their metabolic processes and taxonomic composition in oligotrophic ocean basins has been one of the central tasks of contemporary marine microbial ecology and one of the main challenges in a changing global ocean. However, despite its ecological importance, the South Atlantic Subtropical Gyre (SASG) remains poorly understood in relation to marine microbes, which comprise the major drivers of biogeochemical cycles and the largest carbon sink to the deep ocean. This review presents the state of the art of microbial ecology in the SASG, including the adjacent oligotrophic region, the Southwest Atlantic Ocean (SWAO). We have also addressed the theoretical and methodological trends in this field since 1970s, focusing on the main milestones that led to the more-detailed current knowledge of the role of oligotrophic gyres in the global carbon cycle. Finally, we discussed the general patterns of microbial community composition in the SASG, focusing on their potential responses to environmental factors. In spite of increasing efforts to investigate this region, SASG is among the least known oceanic provinces, which has hampered the debate over whether the oligotrophic ocean acts as a sink or source of $\mathrm{CO}_{2}$ into the atmosphere.

Descriptors: Marine Microbes, Bacterial Production, Biogeochemical Cycles, Oligotrophic Oceans, Pelagic System.

\section{INTRODUCTION}

Microbial plankton is an essential component of marine ecosystems because of its key role in pelagic food-web dynamics and oceanic biogeochemical cycles, including the transport of carbon to the deep ocean (Azam et al., 1983; Cho and Azam, 1990; Gasol et al., 2008) and fixation of an important fraction of the total atmospheric carbon and nitrogen (Worden et al., 2015; Logares et al., 2020).

Marine microbes include a diverse class of heterotrophic and autotrophic prokaryotes as well as

Submitted: $27-N o v-2020$

Approved: 01-Sep-2021

Editor: Hugo Sarmento

C 2021 The authors. This is an open access article distributed under the terms of the Creative Commons license. unicellular eukaryotes (picoeukaryotes), with sizes ranging from $0.2 \mu \mathrm{m}$ to $2.0 \mu \mathrm{m}$ (Sieburth et al., 1978; Fuhrman, 1999). All these microbes, called picoplankton, have large population sizes, short generation times, and nearly unfathomable levels of aquatic biodiversity (Whitman et al., 1998; Thompson et al., 2017).

Bacteria and Archaea are the two domains of heterotrophic prokaryotes that, due to their ubiquity, abundance (on the order of $10^{6}$ cells $\mathrm{ml}^{-1}$ ), high functional diversity and metabolic plasticity, comprise the majority of the biomass in the oceans (Fuhrman et al., 1989; DeLong, 1992). Although these two domains differ in some fundamental aspects of their metabolic features, they have been conventionally referred to as "bacteria" in prior studies. So, here we 
use the terms "bacteria" and "bacterial production" as a collective term referring to bacteria and archaea. The autotrophic picoplankton includes two main groups, photosynthetic cyanobacteria and the single picoeukaryotes, which may account for up to $64 \%$ of the total carbon biomass in oligotrophic open waters (Fogg, 1995).

The ecological and biogeochemical processes in the oceans are dependent on these microbial interactions, which comprise the major drivers of global biogeochemical cycles (Falkowski et al., 2008; 2012). The role of bacteria in marine ecosystems consists largely of consumption of dissolved organic matter, mainly as dissolved organic carbon (DOC) derived from primary production; the bacteria convert the dissolved carbon fraction into particulate organic matter by incorporating it (Fuhrman and Azam, 1980; Azam et al., 1983). Through this process, carbon that was theoretically inaccessible to heterotrophic organisms is reintroduced into food webs by microbes, making it available to higher trophic levels and the deep ocean, illustrating the fundamental role that bacteria play in the microbial loop (Azam and Malfatti, 2007; Pomeroy et al., 2007).

Understanding the dynamics of microbial plankton communities, their taxonomic composition and their metabolic processes has been one of the central tasks of contemporary marine microbial ecology and a main challenge in better understanding the role of microbes in a changing global ocean. During the last five decades, the growing efforts in this area have been impelled mainly by technological advancements and improvements that resulted in the findings that have led to the well-established concepts regarding the marine food web and carbon flow. Most recent approaches have yielded new insights into the role of heterotrophic bacterial production in oligotrophic oceans and in the biological carbon pump, and have also driven the development of new theories, such as the recently proposed microbial carbon pump (Jiao et al., 2014; Legendre, 2015; Zhang et al., 2016).

The implications of global changes for the bacterial community and carbon sinks have been discussed (Morán et al., 2015; Huete-Stauffer et al., 2016; Allen et al., 2020) and studies concerning marine microbial ecology in open ocean basins and subtropical oligotrophic gyres have assumed new importance.
The subtropical gyres, because of their immense size ( $40 \%$ of the surface of the earth) play a significant role in the global carbon cycle and in sequestering atmospheric $\mathrm{CO}_{2}$ through physical and biological processes (McClain et al., 2004; Brix et al., 2006). Therefore, understanding the interactions between these two processes within the subtropical gyres is a central task for determining the magnitude and variability of the carbon exported from the surface to the deep ocean, as well as the $\mathrm{CO}_{2}$ exchange between the atmosphere and the ocean (Signorini et al., 2015).

The South Atlantic Subtropical Gyre (SASG), centered at approximately $50^{\circ} \mathrm{W}$ and $30 / 40^{\circ} \mathrm{S}$, is a distinct biogeochemical province, with unique physical and biological characteristics relative to adjacent regions (Longhurst, 2010; Signorini et al., 2015). This anticyclonic gyre of approximately 4,500 km diameter is bordered by a number of major surface ocean currents and by one of the most oligotrophic areas in the entire ocean on the Brazilian continental shelf (Alves Junior et al., 2015), the Southwest Atlantic Ocean (SWAO) (Figure 1). Despite its ecological importance, the SASG remains little studied compared to other ocean basins.

In this review, we address the state of the art of microbial ecology in the SASG, including the oligotrophic adjacent region (SWAO). We also briefly address methodological trends and conceptual advances in this field, which have led to current wellestablished models of carbon flows in oligotrophic pelagic ecosystems, and the need for understanding whether the oligotrophic ocean is predominantly net autotrophic or heterotrophic. Finally, we discuss the general patterns found in the SASG based on the literature review, focusing on the mechanisms that shape microbial metabolism in this region.

\section{Marine microbial eCOLOgy - Methodological TRENDS AND CONCEPTUAL ADVANCES}

Initially, in an attempt to quantify research contributions to marine microbial ecology over the last five decades, we searched for articles published in peer-reviewed and indexed journals from 1974 through 2020 by the Web of Science portal (www. webofscience.com). The first step of our search was conducted by crossing the terms "bacterioplankton", "marine bacteria", "microbial plankton", "heterotrophic bacteria" or "marine bacterial production", with the 


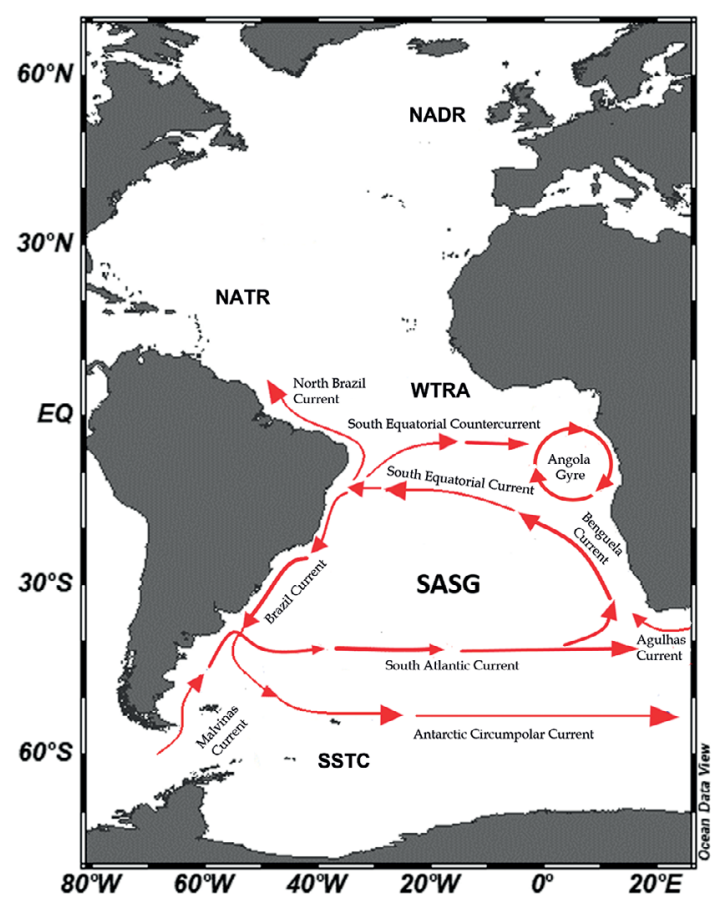

Figure 1. Schematic representation of major current systems that affect the South Atlantic Subtropical Gyre, and the five major biogeochemical provinces of the Atlantic Ocean: North Atlantic Drift Province (NADR), North Atlantic Tropical Gyre (NATL), Western Tropical Atlantic (WTRA), South Atlantic Subtropical Gyre (SASG) and the South Subtropical Convergence (SSTC). Data were plotted in Ocean Data View (Schlitzer, 2020).

keywords regarding to the main methods that contributed to the evolution of marine microbial ecology science: "epifluorescence microscopy", or "thymidine", or "leucine", or "flow cytometry", or "omics" ("metagenomics", "metatranscriptomics", "metaproteomics", "metabolomics", or "metabarcoding"). Since the pioneering work of Pomeroy (1974) was the starting point of this review, the sequential search included publications from 1974 through 2020. In a second step, to select only those studies concerning microbial ecology in marine environments, we conducted a new screening through a search of keywords in the title, and when this was not sufficient, by reading the publication abstract. Our compilation resulted in a total of 758 studies published in marine microbial ecology. However, the first published record on the Web of Science portal dates only from 1978.

In an attempt to provide an overview of conceptual advances that have led to current wellestablished models of carbon flows in oligotrophic pelagic ecosystems, as well as the current debate over whether the oligotrophic ocean is predominantly net autotrophic or net heterotrophic, we provided a timeline highlighting the theoretical and methodological milestones over the last five decades (Figure 2). For this, we also considered the relevant studies in this field that were not registered in our search. In addition, for an overview of methodological trends, we compiled the results from our search by the annual number of publications involving each of the main methods (Figure 3 and Table S1). The main advances in microbial ecology from a historical perspective are addressed below.

\section{MicRobial ECOLOGY IN OLIGOTROPHIC OPEN OCEAN BA- SINS - A HISTORICAL PERSPECTIVE}

From the first perception of the high abundance of bacteria in marine environments to the current post-genomic age, great leaps in marine microbial ecology since the late 1970s have dramatically increased our knowledge in this area, which has become an extremely dynamic field of research in the last five decades. This exponential rate of progress, closely related to the development of technologies and advancement of precision methods, has led to the current high level of understanding of key ocean processes, including bacterial production (BP), respiration (BR), growth efficiency (BGE) and carbon flow through trophic interactions.

After the initial perception of the high abundance of bacteria in marine environments using the epifluorescence microscope and fluorescent dyes (Hobbie et al., 1977; Porter and Feig, 1980), the introduction of radioactive-isotope methods for measuring heterotrophic bacterial production (Fuhrman and Azam, 1980; 1982; Kirchman et al., 1985) inaugurated a new era in studies of microbial dynamics in aquatic environments.

Some early studies using the ${ }^{3} \mathrm{H}$-thymidine and ${ }^{3} \mathrm{H}$-leucine incorporation methods also investigated the coupling between BP and phytoplankton primary production (Hobbie and Cole, 1984; Kirchman et al., 1989). These first investigations were conducted in coastal waters (Pomeroy and Deibel, 1986), inner shelf regions (Fuhrman et al., 1985; Cho and Azam, 1988), estuarine plumes (Ducklow and Kirchman, 1983; Kirchman and Hoch, 1988; Malone and 


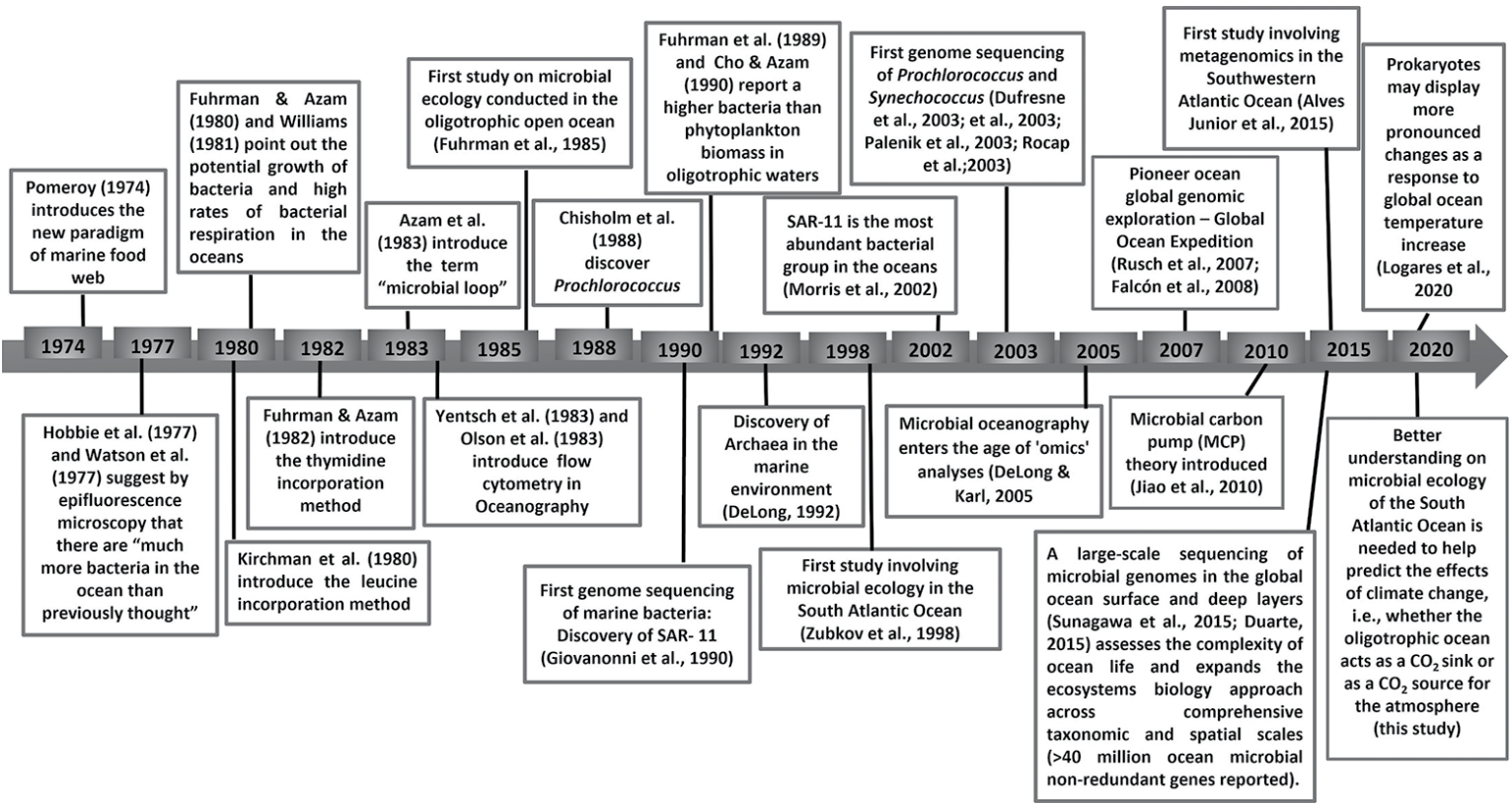

Figure 2. Timeline including the theoretical and methodological milestones over the last five decades (1974-2020) that led to current wellestablished models of carbon flows in oligotrophic pelagic ecosystems, and the need for understanding whether the oligotrophic ocean is predominantly net autotrophic or net heterotrophic.

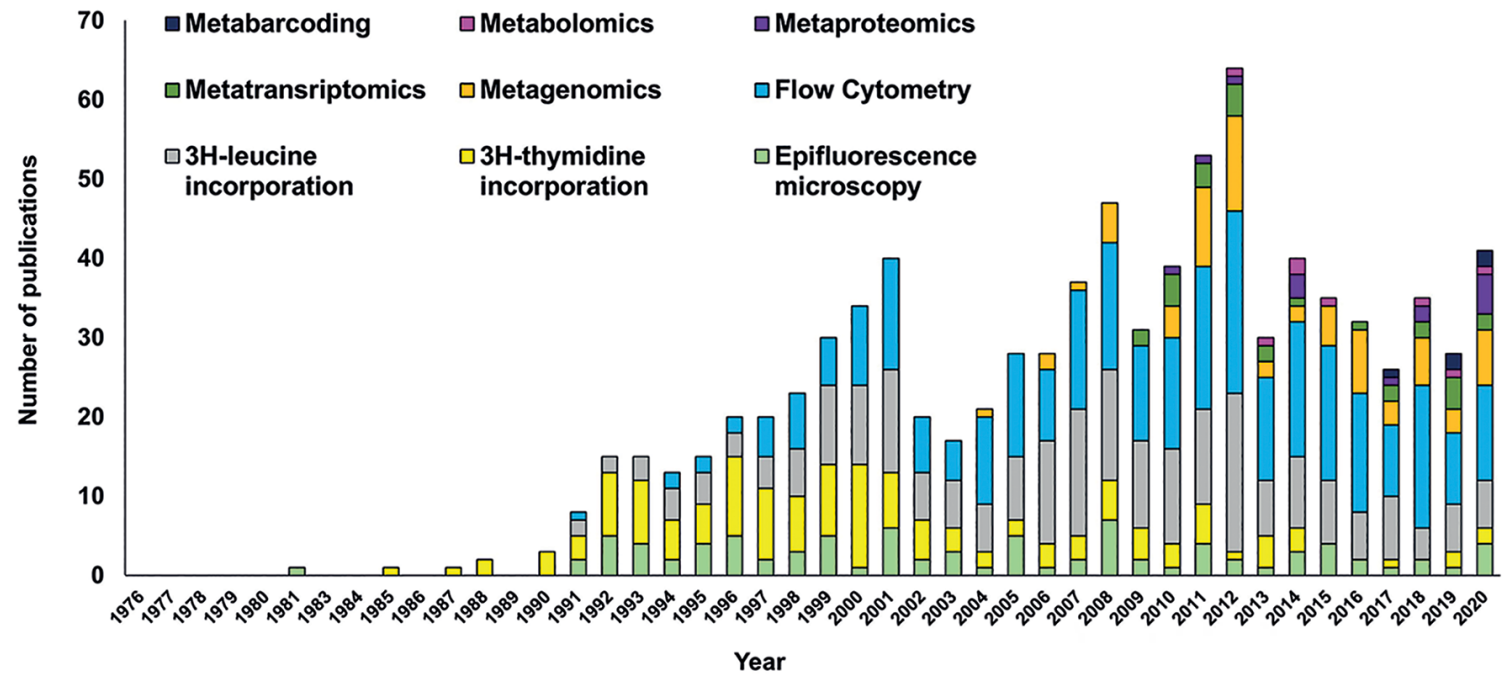

Figure 3. Annual number of citations of each methodology approach resulting from a search for publications on marine microbial ecology by the Web of Science website, from 1974-2020. The keywords "epifluorescence microscopy, 3H-thymidine, 3H-leucine, flow cytometry, metagenomics, metatranscriptomics, metaproteomics, metabolomics and/or metabarcoding were crossing with "bacterioplankton", "marine bacteria", "microbial plankton", "heterotrophic bacteria" or "marine bacterial production".

Ducklow, 1990) and upwelling regions (McManus and Peterson, 1988) of the North Pacific and North Atlantic. Overall, the observations reported in these studies indicated changes in the microbial community along the open ocean to the coastal gradient, i.e., that bacterial biomass and activity were highest near the coast, tending to comprise $<20 \%$ of the phytoplankton biomass and the total particulate organic carbon. However, the first measurements of BP in oligotrophic open oceans, conducted in the euphotic 
zone of the Sargasso Sea and North Pacific Gyre, reported instances where bacterial biomass equaled the phytoplankton biomass (Li et al., 1992) or even exceeded the phytoplankton primary production (Fuhrman et al., 1989; Cho and Azam, 1990).

In part because of this variability, the differences between oceanic regions in microbial loop dynamics and in the fraction of primary production processed by heterotrophic bacteria remained unclear until the discovery of Prochlorococcus cyanobacteria (Chisholm et al., 1988), which completely changed the knowledge of the microbial plankton composition in oligotrophic waters.

Overall, these discoveries stressed the need to investigate the energy balance in different trophic systems and the major oligotrophic oceanic provinces. The energy balance can be expressed by the balance between gross primary production by phytoplankton (GPP) and community respiration (CR), in which bacterial respiration (R) can comprise a large proportion (50 to 90\%) (Rivkin and Legendre, 2001). If $G P P>R$, the system is in a state of net autotrophy and can sustain the export, or sequestration, of dissolved oxygen, reduced carbon, and the potential energy that this represents. Otherwise, if $\mathrm{GPP}<\mathrm{R}$, the system is in a state of net heterotrophy and must import reduced carbon and oxygen to sustain life, also even suggesting an output of $\mathrm{CO}_{2}$ from parts of the ocean to the atmosphere (Karl, 2007).
Until the end of the 1990s, however, microbial ecology in the SAO was completely unknown (Figure 4 and Table S3), and most of the studies of organiccarbon flow through bacterioplankton used empirical models (Del Giorgio et al., 1997; Del Giorgio and Cole, 1998). These studies suggested that the relationship between bacterial grow efficiency (BGE) and $B P$ is variable and that $B G E$ varies systematically with $\mathrm{BP}$, and the trophic richness of the environment increases from marine regions to estuaries (Cole et al., 1988; Cho and Azam, 1988).

In attempt to better understand the coupling between phytoplankton and heterotrophic bacteria and the growing interest in the carbon cycle in the face of ocean global changes, in the last two decades, direct measurements of GPP and R came to be widely used to derive estimates of net community metabolism in the oligotrophic open ocean (Serret et al., 2001), including the first metabolic state assessments of the SASG (Gonzalez et al., 2002; Hoppe et al., 2002; Serret et al., 2002). These studies sometimes report a prevalence of heterotrophy (GPP $<$ R) (Serret et al., 2001; Gonzalez et al., 2002; Hoppe et al., 2002; Duarte et al., 2013), and others a prevalence of autotrophy (GPP $>$ R) (Williams, 1998; Serret et al., 2002; Williams et al., 2013, Tilstone et al., 2015).

In turn, some studies conducted along Atlantic transoceanic transects, have reported alternating patches between heterotrophic and autotrophic net community metabolism on both temporal (Arístegui and Harrison, 2002) and latitudinal scales (González

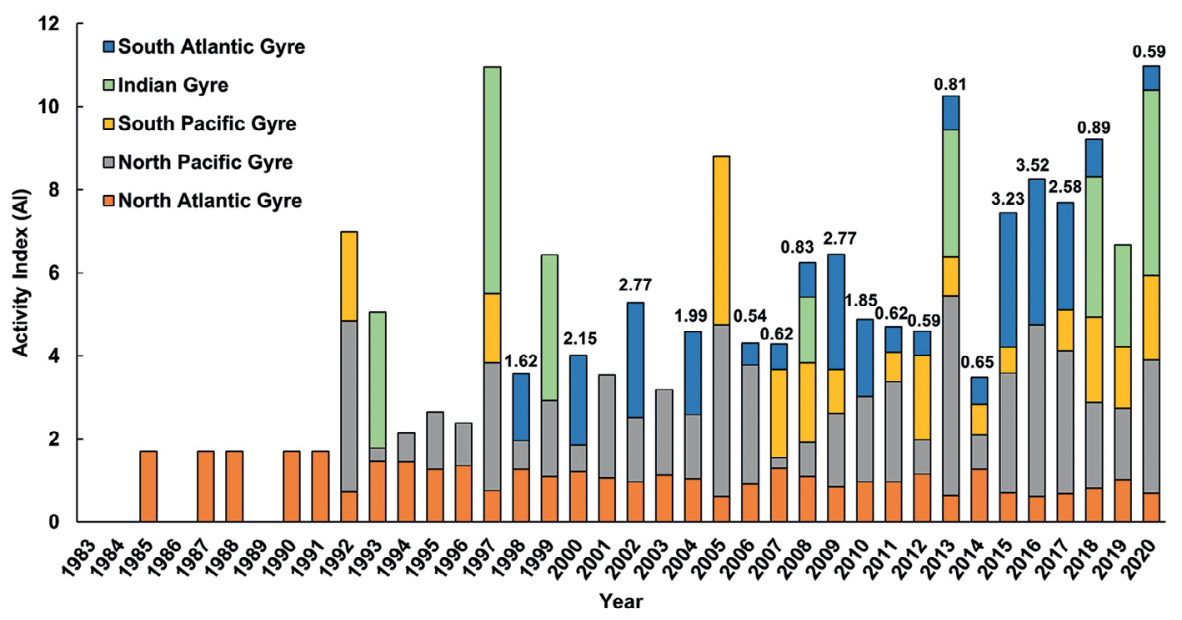

Figure 4. Cross comparison of Activity Index (AI) on marine ecology research from 1985 (year corresponding to the first study in the oligotrophic open ocean) to 2020, between the five major oligotrophic subtropical gyres: North Atlantic Gyre, North Pacific Gyre, South Pacific Gyre, Indian Gyre and the South Atlantic Gyre. The numbers above the bars correspond to Al calculated for SASG. 
et al., 2002; Hoppe et al., 2002), with large net-heterotrophic regions. Overall, these studies have revealed seasonal and geographical patterns, suggesting that the plankton community structure influences the net ecosystem metabolism, thus limiting the predictive ability of GPP:R relationships. Further investigations conducted in the Pacific, Atlantic and Arctic oceans corroborated previous studies, showing that bacterioplankton communities differ among the temperate, subtropical, tropical and polar provinces (Falcón et al., 2008; Gasol et al., 2009; Westberry et al., 2012). These studies also suggest that the variability of $R$, and not only of primary production, needs to be considered in estimations of the ocean metabolic status (Serret et al., 2015).

Despite being intensively investigated, the metabolic balance of oligotrophic gyres remains controversial and an active debate about the carbon balance in oligotrophic pelagic marine ecosystems is still ongoing (Duarte et al., 2013; Williams et al., 2013; Tilstone et al., 2015), highlighting the need to improve knowledge about microbial metabolism in subtropical oligotrophic gyres.

Most recent approaches based on "omics" analyses (metagenomics, metatranscriptomics, metaproteomics, metabolomics and metabarcoding) have provided new insights into the metabolic potential of the oceans and biogeographic patterns (Morales et al., 2011; Stegen et al., 2013; Aylward et al., 2015; Lechtenfeld et al., 2015; Logares et al., 2020). Although these types of analyses do not provide direct information on bacterial production, they are essential to infer microbial community dynamics for the carbon cycle based on its genetic composition and metabolism (DeLong et al., 2006). Genomic and postgenomic analyses, paired with other approaches to evaluate bacterial production, have refined investigations of marine microbial ecology and biogeochemical processes in unprecedented detail. These analyses have also provided important insights to reach a predictive understanding of shifts of microbial communities in a changing global ocean, and consequently of potential changes in carbon flow in the pelagic system (Hutchins and Fu, 2017; Manrique and Jones, 2017; Allen et al., 2020; Grossart et al., 2020).

In turn, metagenomic analyses, designed to address questions related to genetic and biochemical microbial diversity, have revealed the astounding diversity and heterogeneity contained in microbial communities, as well as biogeographic patterns based on metagenomic sequence similarity pertaining to the temperate Atlantic, tropical Atlantic and tropical Pacific oceans, including both coastal and open-ocean sites (Rusch et al., 2007; Falcón et al., 2008). In the last 15 years, important contributions in this field have been provided by ocean expeditions such as the Global Ocean Sampling (GOS) (Rusch et al., 2007), the Malaspina Circumnavigation (Duarte et al., 2015) and the Tara Oceans Project (Sunagawa et al., 2020), which also made it possible to address the question of how microbial communities adjust to global environmental variations on a planetary scale.

Most recent investigations are also focusing on advancing the understanding of how ocean changes such as warming and acidification may affect the biological carbon pump (BCP) and the microbial carbon pump (MCP), as well as the potential transition from dominance of the BCP to the MCP in oligotrophic oceans (Zhang et al., 2017). BCP depends on photosynthetic fixation of $\mathrm{CO}_{2}$ and subsequent carbon export, driven mainly by sinking of particulate organic carbon. The MCP is a component of the BCP concept, used to describe the microbial production of refractory DOM (RDOM), which can be stored for millennia in the deep sea, rather than being respired as dissolved inorganic carbon and returned to the atmosphere (Jiao et al., 2010; Jiao and Azam, 2011). Both processes have significant effects on the air-sea $\mathrm{CO}_{2}$ fluxes on century time scales (IPCC, 2013) and are crucial to ocean carbon flow and climate control.

Current Knowledge of microbial eCology in the South Atlantic Subtropical Gyre

\section{DATA ASSESSMENT}

To assess current knowledge of microbial ecology in the South Atlantic Subtropical Gyre, we performed a new screening from the results of the first step of our search (i.e. methodological approaches) on the Web of Science portal (www.webofscience. com). Through a search of keywords in the title, and when this was not sufficient, by reading the publication abstract, or yet, methodologies, we selected only studies conducted in oligotrophic areas of the SAO: the South Atlantic Subtropical Gyre (SASG) and the Southwestern Atlantic Ocean (SWAO) (Figure 5). 


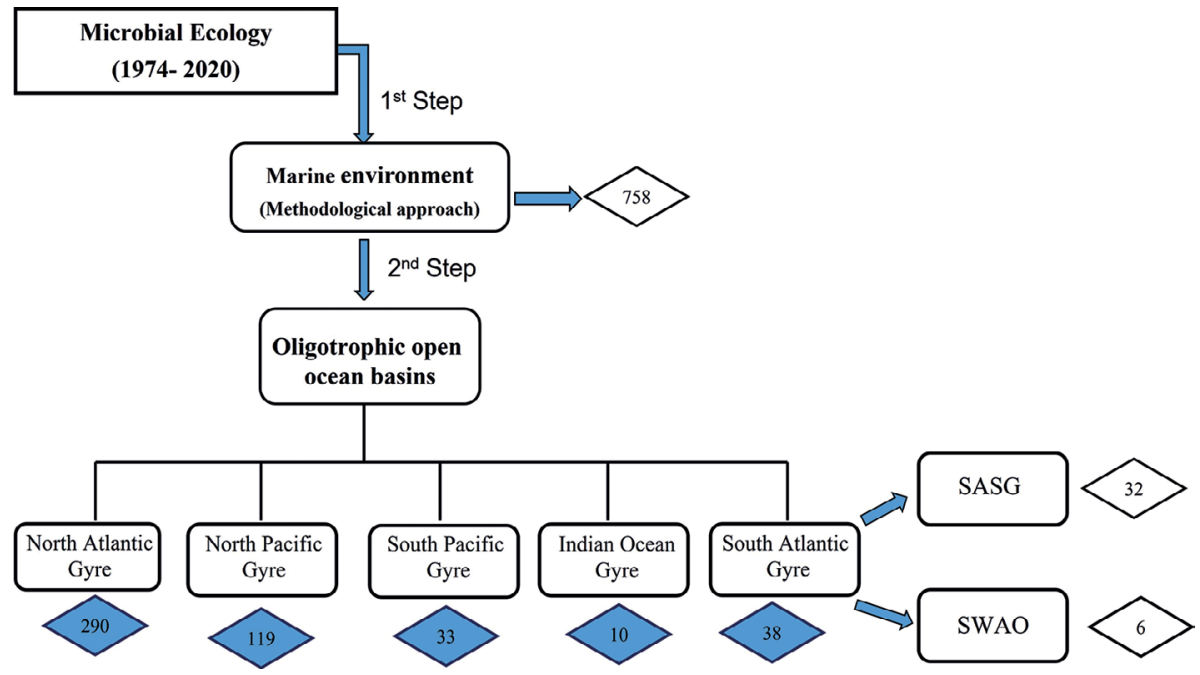

Figure 5. Schematic representation of the main steps of our searching strategy for publications on marine microbial ecology on SASG, through the Web of Science Portal. Black diamonds represent the total number of publications. Blue diamonds represent the total number of citations for the five major subtropical gyres: North Atlantic Gyre, North Pacific Gyre, South Pacific Gyre, Indian Gyre and the South Atlantic Gyre, from 1974 to 2020.

Our search involving microbial ecology in this region resulted in 38 studies, of which 32 were conducted in the open ocean area of the SASG and six in the southwestern Atlantic, comprising the South Brazilian Bight (SBB). This total number suggests that microbial ecology remains poorly studied in the SAO, compared to other oligotrophic ocean basins.

Considering that the simple numerical counting of the absolute number of selected articles can lead to erroneous conclusions (Kumari, 2006), we quantified these contributions by calculating an Activity Index (Al). Initially suggested by Frame (1977) and used in several scientometric assessments (Brusoni and Geuna, 2003; Thomaidis et al., 2000; Kumari, 2006), Al normalizes the publication profile, i.e. one region in relation to the others.

For a cross-comparison between the five major subtropical gyres (North Atlantic Gyre, North Pacific Gyre, South Pacific Gyre, Indian Ocean Gyre and the South Atlantic Gyre), we calculate the Al as follows:

Activity Index (Al) of given gyre $g$ :

Number of Publications in marine microbial ecology (MME) in gyre $g$ in year $y /$ Total number of publications for all years for that gyre / \{ Total MME in all gyres output in year $y /$ Total MME in all gyres output for all years\}.

$\mathrm{Al}=1$ indicates that the number of research studies on the gyre is relatively equal to the other gyres.

$\mathrm{Al}>1$ indicates that research efforts on the gyre are higher than average compared to the others gyres
$\mathrm{Al}<1$ indicates lower research efforts on the gyre compared to the global output.

Despite the absolute number of publications pointing to a greater research effort in the North Atlantic Gyre and North Pacific Gyre (Table S3), the calculated Al showed a great effort in the SASG in some periods over the last twenty years in comparison with the other gyres in the southern hemisphere, mainly between 2015 and 2017 (Figure 4).

In addition, we present the main information from these 38 studies in the SASG and a database of available data on microbial parameters and environmental variables (Table S2). We also compiled the sampling stations where each study was conducted, in an attempt to provide an overview of the studied area in the oligotrophic SAO (Figure 6).

\section{Statistical ANALYSES}

In order to explore general patterns of microbial parameters in the SASG, initially we applied multivariate analysis techniques to the current data (log-transformed) available for those listed by sampling station (Table S2). Principal component analysis (PCA) was applied for microbial plankton abundance (heterotrophic and autotrophic bacteria, eukaryotic picoplankton) and environmental variables (temperature, salinity and inorganic nutrients), to investigate the main environmental drivers of microbial abundance. 

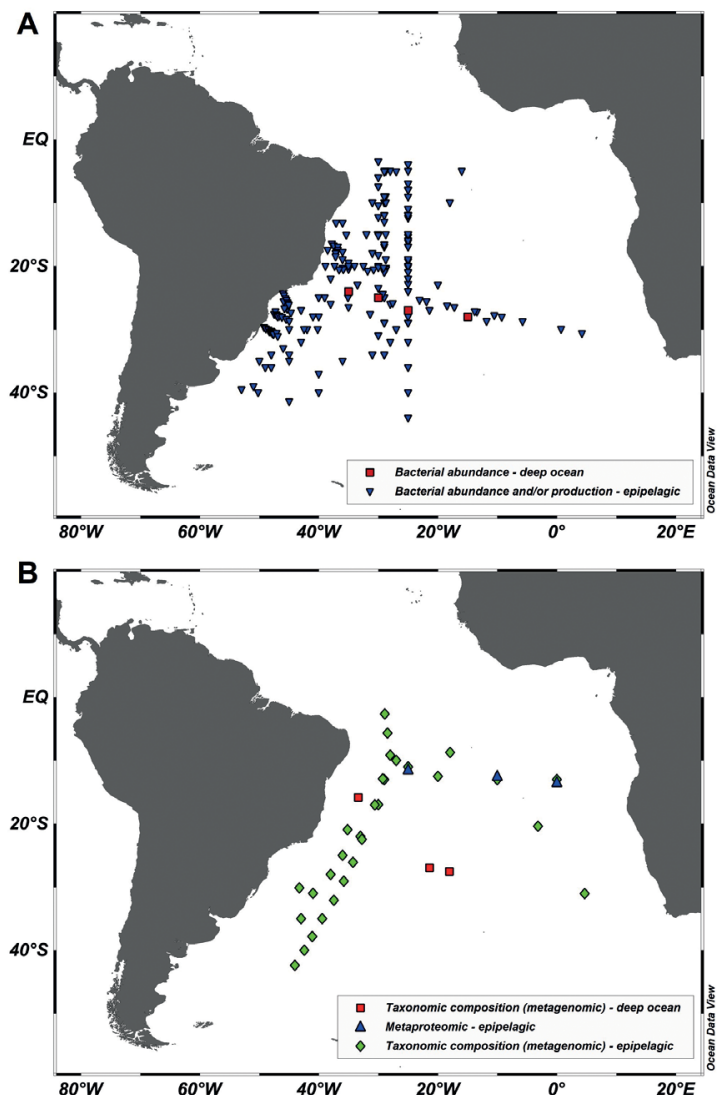

Figure 6. Sampling stations from studies conducted in the SASG and SWAO, extracted from the 38 publications resulting from our review. (A) Studies involving bacterial abundance by flow cytometry/epifluorescence microscopy and/or bacterial production by radioisotopic methods, and/or metabolic state by $\mathrm{O} 2$ method; green triangles indicate studies conducted in the epipelagic zone, red squares indicate studies conducted in the deep ocean. (B) Studies involving metagenomic or metaproteomic analyses (taxonomic or functional composition); green circles indicate metagenomic analyses in the epipelagic zone, blue triangles indicate metaproteomic analyses in the epipelagic zone, and red squares indicate metagenomic analyses in the deep ocean.

Additionally, we performed descriptive statistics using box plots and ANOVA tests to visualize and analyze differences in microbial abundances between regions, seasons and depths. Pearson's correlations and simple linear regressions were also applied to measure the linear dependences between normalized biotic and abiotic data.

For all analyses, the dataset was classified according to the sampling location, SWAO or SASG (western and eastern boundaries of the SASG, or central gyre) and its respective layer (euphotic zone, depth maximum chlorophyll (DCM), or mesopelagic zone).
The PCA analyses were performed using the FactoMinerR package available in $\mathrm{R}$ statistical software version 3.6.3 (Lê et al., 2008). The box plots, followed by an ANOVA test, as well as the Pearson's correlation coefficient and the linear regressions, were performed using the software PAST version 4.02 (Hammer et al., 2001).

\section{Current knowledge in the open ocean of South Atlantic Subtropical Gyre (SASG)}

The pioneer studies concerning microbial ecology in the open ocean of the SASG date only from the last two decades (Figure 4 and Table S3). The first investigations in this region were based on a series of cruises of the Atlantic Meridional Transect (AMT) program which had as one of its main goals to advance understanding of the picoplankton community structure and function over a wide latitudinal range. Focusing on the role of the oceans in the global carbon cycle, these early studies compared the microbial composition (Zubkov et al., 1998; 2000a; 2000c) and heterotrophic bacterial production (Zubkov et al., 2000b) in the North and South Atlantic over a meridional transect from $50^{\circ} \mathrm{N}$ to $50^{\circ} \mathrm{S}$. The composition of the picoplankton community, including heterotrophic bacteria, eukaryotic picophytoplankton, Synechococcus and Prochlorococcus, indicated that this area could be grouped into five large regions, presently called the North Atlantic Drift Province (NADR), North Atlantic Tropical Gyre (NATL), Western Tropical Atlantic (WTRA), South Atlantic Subtropical Gyre (SASG) and the South Subtropical Convergence (SSTC). These results also indicated that heterotrophic bacterial production is lowest in the North and South Atlantic gyres, tending to be highest where the phototrophic biomass is highest.

Over the same transect (AMT), González et al. (2002) investigated microbial metabolism using direct measurements of GPP:R. This study also showed that the region of the South Atlantic Gyre is less productive than the other Atlantic provinces, tending to a net heterotrophic balance $(\mathrm{GPP}<\mathrm{R})$. Hoppe et al. (2002) also investigated the net community metabolism of the South Atlantic Subtropical Gyre in an expanded meridional transect, from $53^{\circ} \mathrm{N}$ to $65^{\circ} \mathrm{S}$. Their results were consistent with previous studies in this region, showing that the South Atlantic was 
in net heterotrophic balance. In contrast, the study conducted by Serret et al. (2002) in the central SASG showed a prevalence of net autotrophy in this region $(G P P>R)$, suggesting the existence of different trophic dynamics in similarly unproductive planktonic communities. Both studies also found that the ratio between BP and primary production was closely related to the meridional profile of water temperature, with a predominance of net heterotrophy in the warm oligotrophic regions.

Later studies also focused on the microbial metabolism underlined the influence of the regional and temporal variability of nutrient inputs on biomass and heterotrophic bacterial production (Hoppe et al., 2006; Vázquez-Domínguez et al., 2008; Zubkov et al., 2008; Gasol et al., 2009; Gist et al., 2009, Otero-Ferrer et al., 2018), reinforcing a global dependence of bacterial activity and production on the nutrient supply.

Focusing on the first predictions of organic matter inputs of atmospheric origin into the oceans (Dentener 2006; Duce 2008), two relevant studies involving microcosm experiments were conducted over a wide latitudinal transect in the Atlantic Ocean, including the central SASG $\left(26^{\circ} \mathrm{N}\right.$ to $\left.29^{\circ} \mathrm{S}\right)$. MartínezGarcía et al. (2010) in an attempt to determine general patterns in the connection between the type of organic matter input, the initial biotic and abiotic conditions and the interactions between microbial compartments, showed that bacterioplankton responses were much higher than phytoplankton responses when both inorganic and organic nutrients were supplied, thus potentially driving the microbial community towards heterotrophy. Teira et al. (2010) investigating changes in the relative abundance of the bacterioplankton community composition at the level of major taxonomic groups observed that distinct groups responded differently to nutrient additions: SAR11 and Bacteroidetes responded negatively to organic and mixed additions, while Roseobacter spp. and Gammaproteobacteria responded positively. A clear increasing gradient from north to south in the magnitude of the Gammaproteobacteria response to organic inputs (containing carbon and nitrogen) suggested a strong link between bacterial community composition and carbon cycling in the oligotrophic ocean.

Other studies focusing on bacterial metabolic activities have assigned temperature as the main driver of bacterial production. Hill et al. (2011) suggested that bacterial activity is a sensitive marker of gyre boundaries and distinct water masses. Mazuecos et al. (2015) through derived PGE indicated a strong correlation between $\mathrm{R}$ and PGE across a temperature gradient, suggesting that temperature variability in the mesopelagic zone plays a significant role in the remineralization of organic matter.

Evans et al. (2015) based on experimental results of light-enhanced uptake of methionine, leucine and ATP by Prochlorococcus and SAR11, provided new evidence of bacterial metabolism, indicating that photoheterotrophy is characteristic of dominant bacterioplankton populations in the global oligotrophic ocean and a widespread biological process in the SASG.

Still focusing on the metabolic state of subtropical oligotrophic gyres, Serret et al. (2015) and Tilstone et al. (2015) provided important contributions to the discussion that is still ongoing. To test the assumption that no regional differences exist in either the $\mathrm{P}: \mathrm{R}$ relationship or the metabolic balance through the oligotrophic ocean, Serret et al. (2015) compiled vertical profiles of the in-vitro GPP, $R$ and net community production (NCP) measurements made during the Atlantic Meridional Transect (AMT) cruises from 2000 through 2012. Based on the differences in both GPP and $\mathrm{R}$, the authors demonstrated the existence of systematic differences in the metabolic state of the oligotrophic North and South Atlantic gyres, reinforcing the previously suggested theory that the oligotrophic ocean is neither auto- nor heterotrophic, but functionally diverse. With the main goal of deriving accurate estimates of net community production, Tilstone et al. (2015) compared a number of empirical approaches using primary production data from satellites with in-vitro measurements of changes in dissolved $\mathrm{O}_{2}$ concentrations in the North and South Atlantic Ocean. Their results showed that the South Atlantic Subtropical Gyre fluctuated from being net autotrophic in austral spring-summer, to net heterotrophic in austral autumn-winter, indicating that recent decadal trends suggest that the SASG is becoming a more important source of $\mathrm{CO}_{2}$.

Finally, in terms of deriving the metabolic state of SASG, García-Martín et al. (2017) conducted direct measurements of bacterial respiration along north to south transects $\left(50.45^{\circ} \mathrm{N}\right.$ to $\left.44.33^{\circ} \mathrm{S}\right)$, including the 
dissolved $\mathrm{O}_{2}$ concentration. Results from this study showed a significantly higher cell-specific bacterial respiration in the temperate and upwelling regions compared with oligotrophic gyres, including the SASG, which suggests that bacterial carbon turnover is slower in this province. The study also showed that the bacterial contribution to depth-integrated community respiration varied widely within provinces (4$77 \%)$, suggesting that the proportion of total community respiration attributable to bacteria is similar in the different oceanographic regions studied.

Concerning -'omics" analyses, the first studies using genomic approaches in the SASG have agreed with these previous studies, also showing different patterns of latitudinal distribution of the taxonomic composition and diversity of the bacterial community. Schattenhofer et al. (2009) and Morris et al. (2012) showed that SAR11 bacterioplankters are less abundant in the South Atlantic than in the North Atlantic, and that the biomass of Prochlorococcus reached its peak in this region. Morris et al. (2010), conducted the first and unique metaproteomic study in the SASG and indicated that the microbial community structure also shifted along the nutrient concentration gradients, from the open ocean to the coast. Swan et al. (2014) were the first to investigate the genomic and metabolic diversity of Thaumarchaeota, one of the most abundant and cosmopolitan chemoautotrophs within the global dark ocean. This study, however, included only one sampling station in the mesopelagic zone of the SASG.

Important contributions for current knowledge of microbial structure, diversity, function, activity and biogeographical patterns in the SASG were provided by the Tara Oceans Project, Malaspina Circumnavigation Expedition and the GEOTRACES cruises. Metagenomic data from these global expeditions are available from Sunagawa et al. (2015), Tully et al. (2017), Biller et al. (2018) and Sanz- Saéz et al. (2020).

Overall, these studies assessed patterns of diversity and marine stratifying factors of the microbial community composition from different depths, generating unprecedented amounts of environmental sequencing data and making it possible to address the question of how microbial communities respond to global environmental variations. The Malaspina
Expedition, in turn, provided an unprecedented assessment of the state of the dark ocean, allowing for the first global assessment of bacterial abundance in mesopelagic and bathypelagic waters of the main ocean basins. Data on the bacterial abundance in the SASG deep ocean are available from Pernice et al. (2015). Tully et al. (2017) reconstructed microbial genomes from these metagenomics samples, presenting 360 additional draft genomes from the SAO samples for Bacteria and Archaea.

In light of the need to understand the current and future configuration of marine microbes in the global ocean, recent studies examined the ecological mechanisms that shape these microorganisms in surface waters on a planetary scale. From samples obtained from the Tara Ocean Project and the Malaspina Expedition, Logares et al. (2020) identified patterns using amplicon sequencing data, suggesting that the surface water picoplankton may not show a single response to global change, and that perhaps prokaryotes will display more pronounced changes in their community structure as a response to temperature increase than picoeukaryotes.

Finally, the most recent study on SASG analyzed a collection of 31 metagenomes including the epipelagic, mesopelagic and bathypelagic zones (Coutinho et al., 2021). By revealing that many of these genomes are derived from poorly characterized taxa of Bacteria and Archaea, these results reinforce the lesser attention that the SASG microbiome has received compared to other regions of the global ocean.

\section{Current knowledge of the Southwest Atlantic OCEAN (SWAO)}

Microbial communities in the Southwest Atlantic Ocean (SWAO) off Brazil are beginning to be investigated, but studies conducted in the southwestern portion of the SAO, especially on the inner shelf of the South Brazilian Bight (SBB), have also provided evidence of the dependence of bacterial production on the nutrient supply, the coupling of heterotrophic bacteria and primary producers, as well as the temporal variability in the metabolic state of open oligotrophic waters.

The SWAO is one of the most oligotrophic areas in the entire ocean (Alves Junior et al., 2015); the waters on the Brazilian continental shelf, which 
are predominantly autotrophic, are fertilized during spring and summer by the onshore intrusion of the oceanic South Atlantic Central Water (SACW), a cold and nutrient-rich water mass (Castro et al., 2006).

The first study concerning bacterial dynamics in the SWAO (Andrade et al., 2004) was conducted over a broad area of the Atlantic Ocean, from São Tomé Cape (ST Cape; $22^{\circ} \mathrm{S}, 41^{\circ} \mathrm{W}$ ) to the Salvador coast $\left(13^{\circ} \mathrm{S}, 38^{\circ} \mathrm{W}\right)$, and off the Brazilian oceanic islands Trindade and Martim Vaz $\left(20^{\circ} \mathrm{S}, 29^{\circ} \mathrm{W}\right)$. The authors conducted a preliminary characterization of bacterioplankton in this region and evaluated the heterotrophic bacterial abundance and production over this large spatial scale. Their results addressed the relationship of bacteria distribution and activity to upwelling phenomena in this area of the southwestern Atlantic Ocean.

In the same region, Andrade et al. (2007) investigated the distribution pattern of the high nucleic acid content (HNA) and low nucleic acid content (LNA) bacteria, and their relationship to physical and chemical features. Their results showed the distribution of these groups in two different oceanic provinces, from coastal waters to the open ocean: HNA bacteria were dominant in warmer waters with riverine nutrient inputs, and LNA bacteria were the dominant cells in regions with higher nitrate levels.

To assess the distribution of pico- and nanoplankton communities in different water masses on the inner shelf of the South Brazilian Bight (SBB), Ribeiro et al. (2016a; 2016b) determined the abundance of heterotrophic bacteria, Prochlorococcus, Synechococcus and autotrophic pico- and nanoeukaryotes along three transects extending from $23^{\circ} \mathrm{S}$ to $31^{\circ} \mathrm{S}$ and $39^{\circ} \mathrm{W}$ to $49^{\circ} \mathrm{W}$. The results obtained from this study agree with observations in other marine areas, where Synechococcus and autotrophic eukaryotes dominate the mesotrophic waters, while Prochlorococcus dominates in oligotrophic areas. Using the same approach, Bergo et al. (2017) assessed the influence of a summer intrusion of the South Atlantic Central Water (SACW) on the spatial and vertical dynamics of plankton abundance and carbon biomass across environmental gradients. Regarding the importance of each group to carbon biomass partitioning, the authors showed that the dominance of heterotrophic bacteria is governed by upwelling conditions, while the relative contribution of each phytoplankton group is more evenly distributed when the SACW is not as influential.

Finally, we highlight the first metagenomic study conducted in the SWAO, which covered the Abrolhos Bank and the Campos Basin (from $-08^{\circ}$ to $-23^{\circ}$ latitude), both in the southwestern Atlantic (Alves Junior et al., 2015). This study was the first attempt, and unique until now, to characterize the taxonomic and functional community diversity along the depth continuum and different water masses in the SWAO and to compare this diversity with the microbial community diversity of the global ocean. The results showed that the SWAO has a significant proportion of endemic genetic diversity and a unique microbial signature. SWAO microbial communities share genes with the global ocean in at least 70 cellular functions; however, more than a third of reported genome sequences comprise a unique gene pool in the global ocean. This interesting study suggests that the SWAO is maybe a hotspot of microbial diversity.

\section{DISCUSSION}

Despite the facilities provided by the method used in our search for scientific articles, it is possible that some restrictions in this database have resulted in an underestimation of our results concerning studies on marine microbial ecology. Thus, we must consider our result ( $n=758$ ) as a rough estimate of the total scientific publications over these years, which in turn allowed us to address the methodological trends and the main conceptual advances in this field over the last five decades, regarding oligotrophic pelagic ecosystems.

These same facilities allowed us to easily access publications that have at least one sampling station in the region of interest (SASG/SWAO), and compile the number of publications in each of the five main subtropical gyres used to calculate the Al (Figure 5).

Despite the last two decades of experimental and field observations, four central issues have hampered efforts to effectively improve knowledge of the mechanisms that shape microbiological and biogeochemical processes in this region: 1) the controversy over its metabolic balance/state, 2) the main drivers of biogeographic patterns in the microbial community composition, 3) lack of knowledge about taxonomic composition, 4) spatial and temporal undersampling, especially in deep layers. 
Since the balance between net autotrophic and heterotrophic production by direct measures of GPP and $\mathrm{R}$ was the most investigated topic in the SASG, the spatial distribution and temporal variability of the sampling, as well as differences due to the use of different methods, may explain the lack of agreement on its metabolic state.

Concerning the differences in spatial distribution, the first investigations conducted in the SASG already suggested the existence of different trophic dynamics within the gyre. Gonzales et al. (2002) and Hoppe et al. (2002) investigating the western boundary of the SASG showed a net heterotrophic balance ( $\mathrm{R}>\mathrm{GPP}$ ), while Serret et al. (2002) investigating the central SASG showed a prevalence of net autotrophy $(G P P>R)$. A series of other studies have also reported differences in the metabolic state of the SASG, including seasonal trends (Vasquez-Dominguez et al., 2008; Zubkov et al., 2008; Gasol et al., 2009; Serret et al., 2015; Tilstone et al., 2015). Overall, these studies reinforce the existence of regional and temporal variability in the trophic dynamics of the gyre, suggesting that the influence of nutrient inputs may be more important than temperature in the regulation of bacterial growth characteristics on a large spatial scale.

Later studies focusing on bacterial metabolic activities, however, attributed temperature as the main driver of biomass and heterotrophic bacterial production (Hill et al., 2011; Mazuecos et al., 2015, Logares et al., 2020). The geographic pattern of the net community metabolism was also attributed to the functional diversity of the SASG pelagic ecosystem, highlighting to the relative importance of local vs. allochthonous sources of organic matter. Since the responses of heterotrophs and autotrophs to nutrient inputs are different (Martínez-García et al., 2010; Teira et al., 2010), it is suggested that different processes control bacterial dynamics in oligotrophic waters.

Over the last five years, the advancement of metagenomic studies in the SASG, as well access to the taxonomic and genomic content of global ocean microbial communities (Sunagawa et al., 2015; Tully et al., 2017; Biller et al., 2018; Logares et al., 2020; Sans-Saéz et al., 2020; Coutinho et al., 2021), have provided new evidence of the diversity and functional patterns of this region. This new evidence has also emerged with new questions, suggesting that the geographic pattern of net community metabolism may be related to the functional diversity of each ocean basin.

This variability between regions and years is expected due to differences in the physicochemical characteristics and microbial community composition. In an attempt to find general patterns in the SASG that would illuminate some of these questions, we conducted statistical analysis using microbial abundance and environmental parameters of data currently available (Table S2). These analyses allowed us to explore some of these issues and provide support to answer the following questions: Are there any geographic, seasonal and/or depth patterns in the abundance and diversity of microbial plankton subgroups in the oligotrophic SAO (SASG/SWAO)? Are there different patterns of these variables within the gyre (SASG)? What are the main environmental drivers shaping these microbial parameters in these regions?

The first PCA analysis $(n=334)$ applied to both regions of oligotrophic SAO (SASG/SWAO) indicated that the first two components are sufficient to explain $90.6 \%$ of the total variance of microbial and environmental variables (Figure 7A). PC1 explained $57.9 \%$ of the data variability, while PC2 explained $32.7 \%$ of the variability. The highest contributions to $\mathrm{PC} 1$ were eukaryotic picoplankton, $\mathrm{PO}_{4}$ and $\mathrm{NO}_{2}$, while the highest contributions to $\mathrm{PC} 2$ were temperature, heterotrophic bacteria and $\mathrm{NO}_{3}$. These results showed a strong relationship between heterotrophic bacterial abundance and temperature, and between autotrophic picoplankton and $\mathrm{NO}_{3}$ concentration in both regions. The biplot graph also showed the grouping of samples according to the spatial (SASG vs. SWAO) and vertical distribution. For samples from mesopelagic zones, it is possible to notice similarities for both regions. For the euphotic zone of the SWAO, no spatial distribution pattern was observed.

To further explore spatial patterns in the SASG, we applied an additional PCA $(n=170)$ including only the different areas of the gyre (central (SASG), western boundary (WB-SASG) and eastern boundary (EB-SASG)). For this PCA analysis (Figure 7B), the two components explained $99 \%$ of the total variance. PC1 explained $76 \%$ of the variability, while PC2 explained $23 \%$. Heterotrophic bacteria, salinity and $\mathrm{PO}_{4}$ were the major contributors to $\mathrm{PC} 1$, while nitrate and eukaryotic picoplankton were the main contributors to PC2. This biplot indicated a clear vertical and geographic pattern, showing that in the euphotic zone 


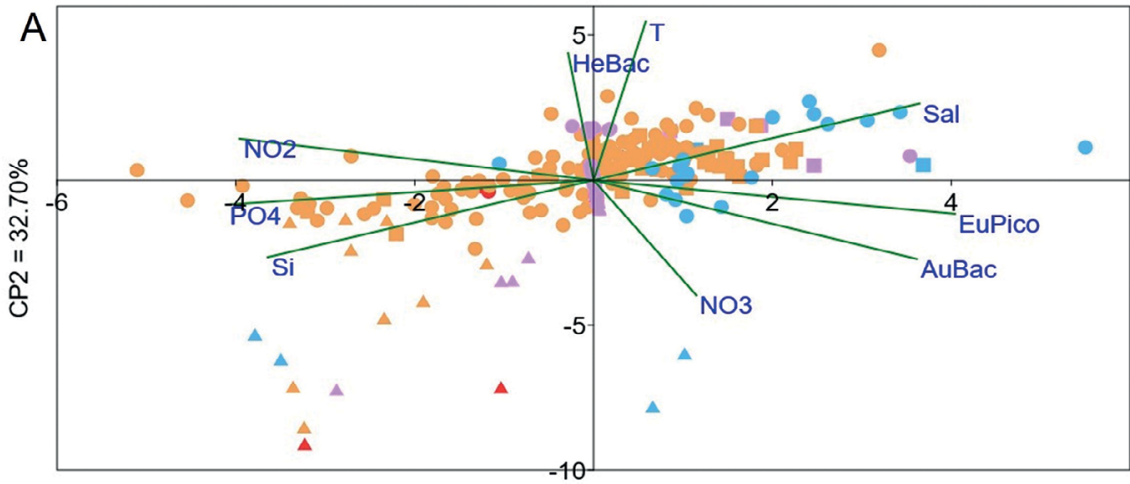

$\mathrm{CP} 1=57.88 \%$

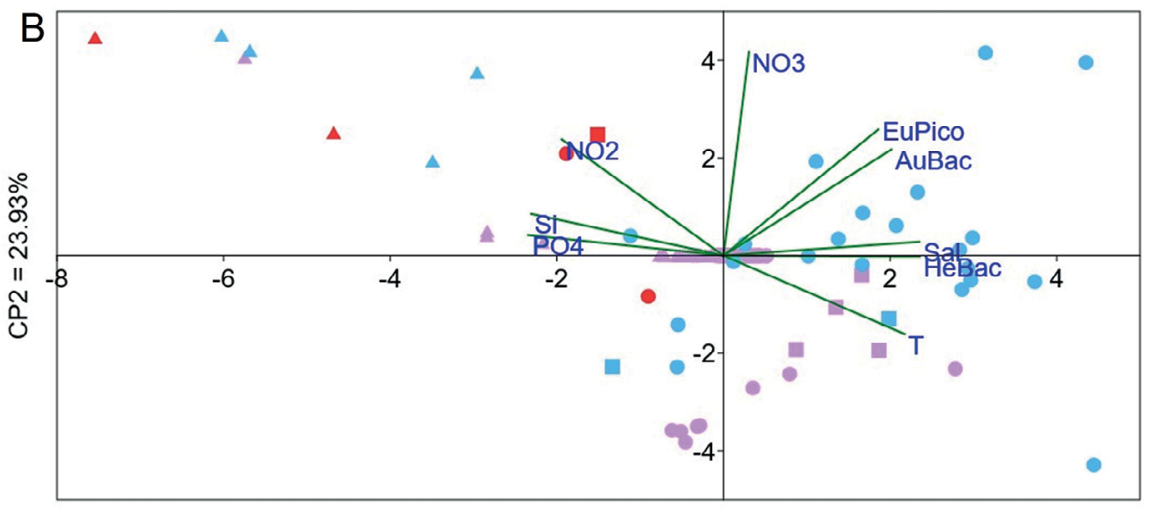

$\mathrm{CP} 1=76.07 \%$

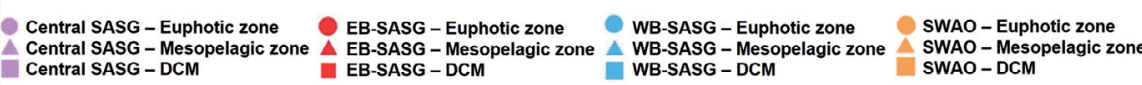

Figure 7. Biplots of the principal component analysis (PCA) of microbial abundances from flow cytometry (heterotrophic bacteria (HeBac), autrotrophic bacteria (AuBac), eukaryotic picoplankton (EuPico)) and environmental parameters (temperature (T), Salinity (Sal), Phosphate (PO4), Nitrate (NO3), Nitrite (NO2) and Silicate (Si)) for the oligotrophic regions of SAO. Circles represent the data in the euphotic zone, squares represent the samples from the depth of chlorophyll maximum (DCM), and triangles represent the samples in the mesopelagic zone. The size of the lines indicates the contribution of the components. Different colors represent the different regions: (lilac) central SASG, (red) eastern boundary of the SASG (EB-SASG), (blue) western boundary of the SASG (WB-SASG), (orange) the oligotrophic SWAO. (A) PCA applied for SASG and SWAO. (B) PCA applied only for the different regions in the SASG.

of the western boundary of the SASG, autotrophic picoplankton and $\mathrm{NO}_{3}$ are positively correlated, while heterotrophic bacteria are more connected with the temperature in the euphotic zone of the central and western boundary of the SASG.

The analysis of the box plots, followed by verification of the result of the ANOVA test, both performed to investigate the differences in microbial abundance between regions, seasons and depths, indicated significantly higher abundance ( $p$-value $<0.001)$ of heterotrophic bacteria in the SWAO region compared to the SASG (Figure 8A), but lower abundance of autotrophic bacteria when compared to the western boundary of the SASG (WB-SASG) (Figure 8D). When contrasting microbial abundance between seasons, heterotrophic bacteria showed a more homogeneous distribution, whereas autotrophic bacteria were significantly ( $p$-value $<0.001)$ higher in autumn than in spring or summer (Figure 8E). Interestingly, the abundance of eukaryotic picophytoplankton did not show significant differences between seasons or between study regions (Figure $8 \mathrm{G}$ and $\mathrm{H}$ ). Regarding depth, significant differences ( $p$-value $<0.01$ ) in microbial abundance were found along the water column, being significantly lower in the mesopelagic zones than in the DCM and euphotic zones (Figure 8C, F and I).

In addition, the analysis of Pearson's correlation coefficients ( $r$ ) (Table 1) showed a strong positive correlation between temperature and heterotrophic 

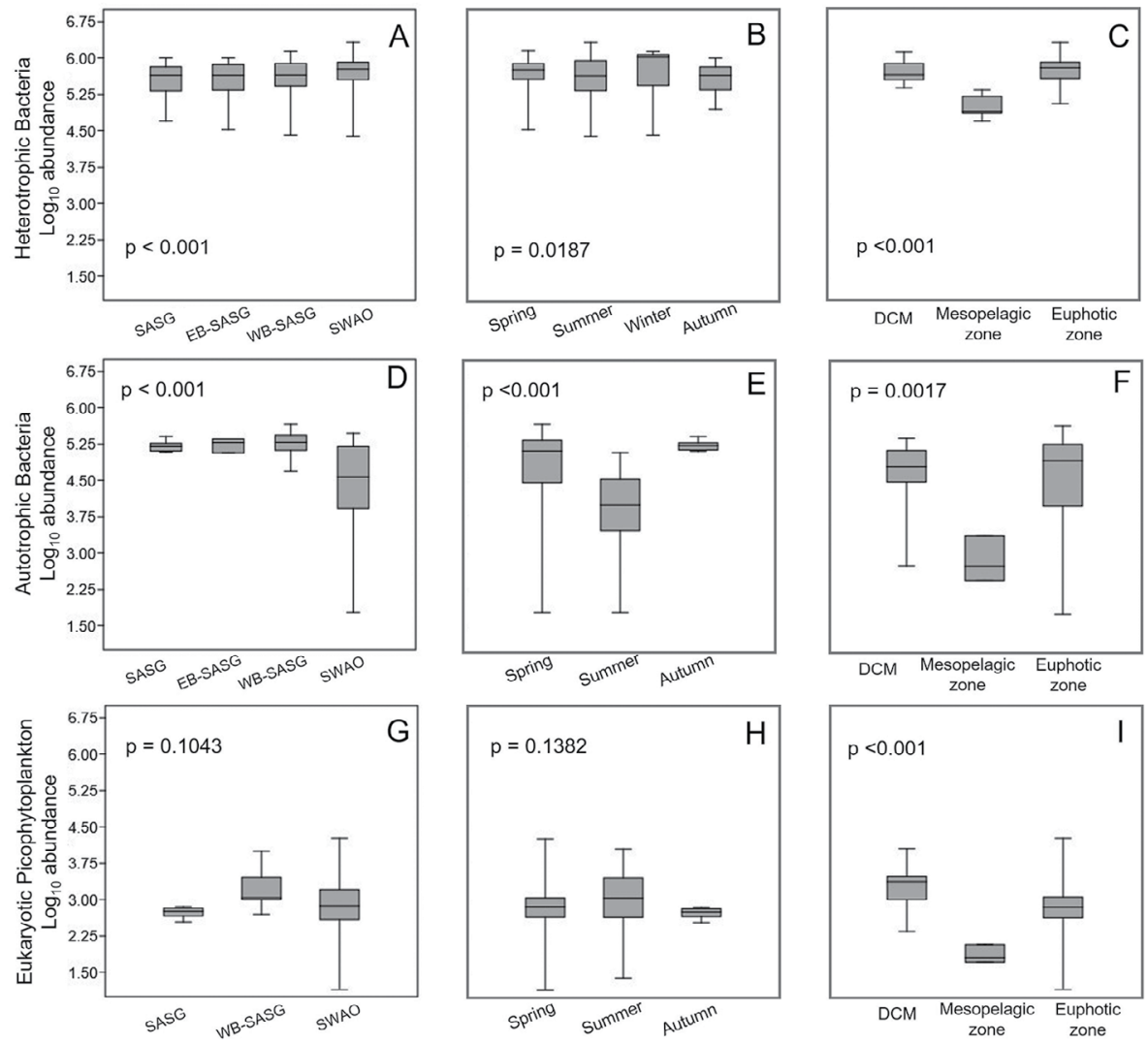

Figure 8. Box plots of microbial abundance data from flow cytometry (Log10 abundance): (A-C) Heterotrophic bacteria, (D-F) Autotrophic bacteria, (G-I) Eukaryotic picophytoplankton. Data are grouped according to study region (central SASG (SASG), eastern boundary of the SASG (EB-SASG), western boundary of the SASG (WBSASG), and SWAO), season (spring, summer, autumn and winter) and pelagic zone (DCM, mesopelagic and euphotic zone). The $p$-values obtained in the ANOVA tests are indicated in the graphs, for each data group.

Table 1. Pearson's correlation coefficient (r) between microbial abundances from flow cytometry (heterotrophic bacteria (HeBac), autrotrophic bacteria (AuBac), eukaryotic picoplankton (EuPico)) and environmental parameters (Temperature (T), Salinity (Sal), Nitrate $\left(\mathrm{NO}_{3}\right)$, Nitrite $\left(\mathrm{NO}_{2}\right)$, Phosphate $\left(\mathrm{PO}_{4}\right)$, Silicate (Si), and Chlorophyll fluorescence (Flu)).

\begin{tabular}{|c|c|c|c|c|c|c|c|c|c|c|c|}
\hline & HeBac & AuBac & EuPico & Depth & $T$ & Sal & $\mathrm{NO}_{3}$ & $\mathrm{NO}_{2}$ & $\mathrm{PO}_{4}$ & $\mathrm{Si}$ & Flu \\
\hline HeBac & 1 & & & & & & & & & & \\
\hline AuBac & 0.512 & 1 & & & & & & & & & \\
\hline EuPico & 0.534 & 0.466 & 1 & & & & & & & & \\
\hline Depth & -0.654 & -0.518 & -0.197 & 1 & & & & & & & \\
\hline $\mathbf{T}$ & 0.714 & 0.511 & 0.190 & -0.646 & 1 & & & & & & \\
\hline Sal & 0.210 & 0.121 & -0.050 & -0.264 & 0.634 & 1 & & & & & \\
\hline $\mathrm{NO}_{3}$ & -0.635 & -0.666 & -0.232 & 0.661 & -0.787 & -0.486 & 1 & & & & \\
\hline $\mathrm{NO}_{2}$ & 0.291 & -0.082 & 0.204 & -0.036 & 0.185 & 0.017 & 0.110 & 1 & & & \\
\hline $\mathrm{PO}_{4}$ & -0.356 & -0.336 & -0.217 & 0.457 & -0.604 & -0.528 & 0.629 & 0.066 & 1 & & \\
\hline Si & -0.295 & -0.117 & 0.193 & 0.414 & -0.643 & -0.660 & 0.598 & -0.048 & 0.800 & 1 & \\
\hline Flu & 0.255 & 0.258 & 0.569 & 0.168 & 0.017 & 0.017 & -0.070 & 0.347 & -0.068 & 0.126 & 1 \\
\hline
\end{tabular}

bacterial abundance $(r=0.71)$ and a moderate positive correlation with the abundance of autotrophic bacteria $(r=0.51)$, which were corroborated by linear regressions (Figure 9). Depth was negatively correlated with heterotrophic $(r=-0.65)$ and autotrophic $(r=$ -0.52 ) bacterial abundance, which was also revealed 

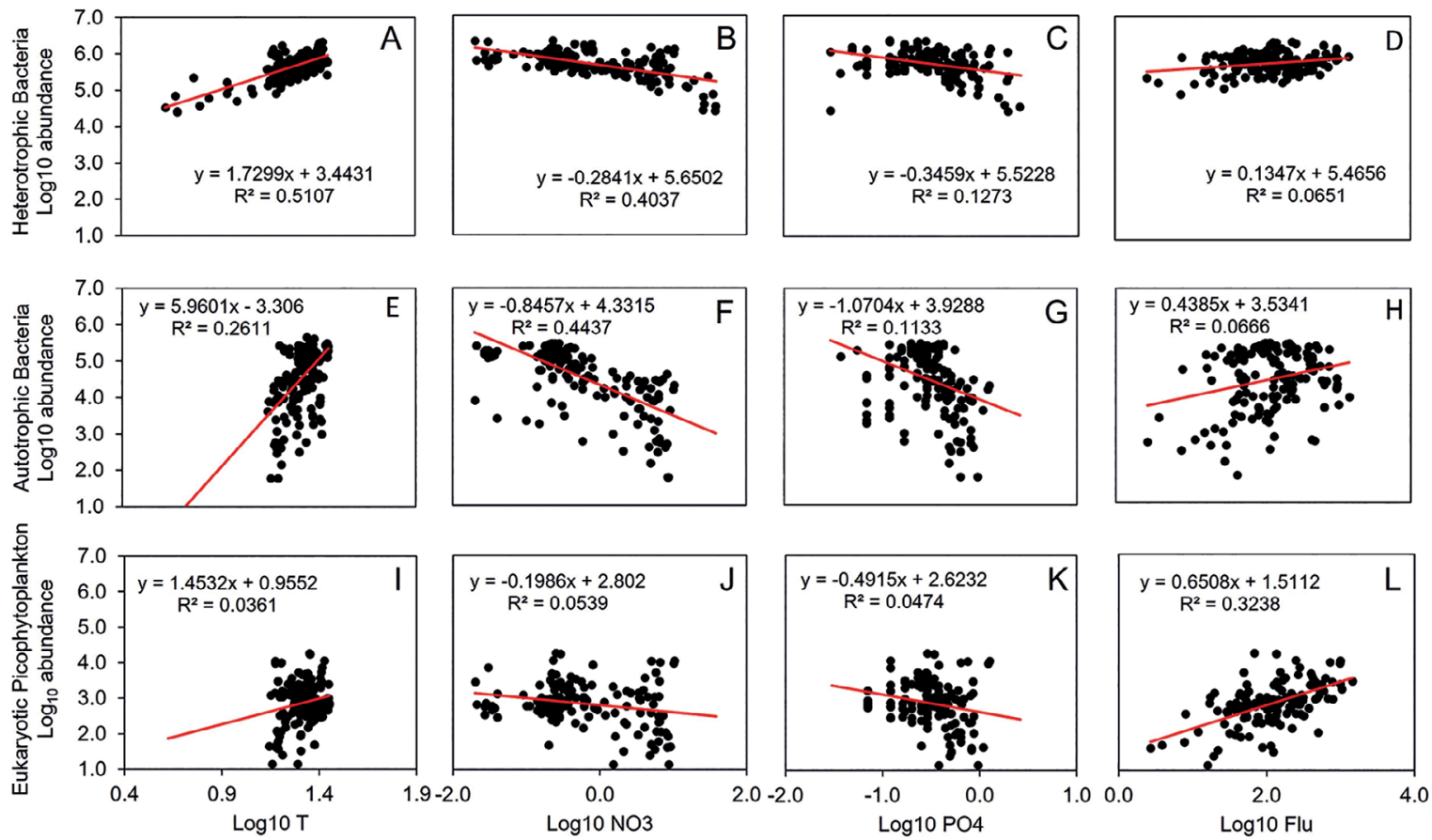

Figure 9. Linear regressions between microbial abundance data from flow cytometry and environmental parameters (temperature ( $\mathrm{T}$ ), nutrients $\left(\mathrm{NO}_{3}\right.$ and $\mathrm{PO}_{4}$ ) and chlorophyll fluorescence (Flu)): (A-D) Heterotrophic bacteria, (E-H) Autotrophic bacteria, and (I-L) Eukaryotic picophytoplankton.

by box plot analyses. Nutrient concentrations, mainly $\mathrm{NO}_{3}$ and $\mathrm{PO}_{4^{\prime}}$ also showed negative correlations with bacterial abundance. This trend was especially observed for autotrophic bacteria versus nitrate (Figure 9F). The abundance of eukaryotic picophytoplankton showed a positive correlation with chlorophyll fluorescence $(r=0.57)$, which was corroborated by the linear regression (Figure $9 \mathrm{~L}$ ).

Overall, these analyses support biogeographic patterns of microbial communities in different areas of oligotrophic SAO (SASG vs. SWAO), between two areas within the gyre itself (i.e., marginal vs. central), as well as differences between seasons and depths. They also indicate the relative importance of different local vs. allochthonous sources of organic matter on microbial structure, suggesting that SASG is predominantly autotrophic, acting as $\mathrm{CO}_{2}$ sink.

At an ocean-wide scale, different environmental conditions regulate the growth characteristics of picoplankton. While the growth of autotrophic bacteria and eukaryotic picophytoplankton are supported by nutrients, the growth of heterotrophic bacteria is partially supported by organic compounds produced by phytoplankton cells and remineralization of inorganic nutrients (Azam et al., 1983). Thus, due the coupling between phytoplankton and heterotrophic bacteria, changes in the microbial community are expected along a nutrient gradient and under different environmental conditions. This explains the highest abundance of heterotrophic bacteria in SWAO compared to SASG, and the highest abundance of autotrophic bacteria in the SASG.

The growth of heterotrophic bacteria in SWAO benefits from increased organic matter derived from phytoplankton communities and allochthonous sources (Susini-Ribeiro et al., 2013, Brandini et al., 2014). The growth of autotrophic bacteria in WB-SASG is influenced by the seasonal (spring-summer) intrusion of the nutrient-rich South Atlantic Central Water (SACW) along the adjacent continental shelf of SWAO (Castro et al., 2006, Ribeiro 2016b, Bergo et al., 2017), which promotes fertilization of the euphotic layer through a shift from regenerated to new production (Metzler et al., 1997). In the most central SASG and eastern boundary, the highest abundance of autotrophic bacteria is supported by Prochlorococcus, which dominate in more oligotrophic areas (Partensky et al., 1999). Regarding the differences between seasons, 
the lower abundance of autotrophic bacteria in spring and summer can also be explained by the upwelling phenomena on the SWAO continental shelf (Ribeiro et al., 2016b, Bergo et al., 2017), which favors the growth of larger phytoplankton cells. With respect to eukaryotic picophytoplankton, their ability to move in the water column in response to different light and nutrient gradients to improve their optimal growth conditions (Raven, 1998) may explain their positive correlation with chlorophyll fluorescence.

Since photosynthesis (GPP) and respiration (BP) mediate the exchange of $\mathrm{CO}_{2}$ between the oceans and atmosphere (Duarte et al., 2013, Tilstone et al., 2015), this strong link between microbial plankton communities and environmental conditions may provide indication of their role in the carbon cycling in the oligotrophic ocean, and therefore be appropriate to monitor the effect of possible changes in these conditions at the microbial level (Hoppe, 2006). Thus, considering that temperature seems to affect more prokaryotic assemblages than picoeukaryotes, and that prokaryotes would present more pronounced changes in their community structure in response to temperature increase on a planetary scale (Logares, 2020), the need for improvements is clear for providing data in open ocean basins and poorly studied subtropical oligotrophic gyres, such as the SASG.

Previous studies also corroborate these statements, indicating shifts in the structure and diversity of microbial metabolism induced by the sea surface temperature warming and ocean acidification (Sarmento et al., 2010; Morán et al., 2015; HueteStauffer et al., 2016, Louca et al., 2016). Experimental studies using microcosms have also revealed the different responses of food web components to warming, through changes in biomass, production, respiration, and lower growth efficiency (Hoppe et al., 2008; Wohlers et al., 2009; Sarmento et al., 2010; Lara et al., 2013). Reductions in bacterial size, through genome sizes, have also proved to be a short-term response to increasing temperature in experimental incubations (Morán et al., 2015; Huete-Stauffer et al., 2016). Moreover, the composition of bacterioplankton community changed consistently in response to elevated $\mathrm{CO}_{2}$ at the ultraoligotrophic center of the South Pacific Gyre (Allen et al., 2020).

In view of the direct and indirect evidence that indicate changes in tropical and subtropical oligotrophic gyres (Hill et al., 2011; Hu et al., 2017; Zhang et al., 2017), a shift in the balance between autotrophic production and heterotrophic consumption of organic matter is expected. A community dominated by smaller cells, mainly heterotrophic bacteria, would favor respiration of carbon in the microbial loop and reduction of the rate of carbon sequestration. The consequences of these changes for ocean ecosystems can be summarized as a potential reduction in the transfer of organic matter to higher trophic levels, bacterial losses to their grazers (Wohlers et al., 2009) and weakening of the biological and microbial carbon pump, with a positive feedback to the rising atmospheric $\mathrm{CO}_{2}$ (Evans et al., 2011; Morán et al., 2015; Zhang et al., 2017) and potential changes in carbon flow in the pelagic system.

All of these issues support the need to conduct large-scale cruises and long-term monitoring programs across the SASG, in an attempt to integrate data on bacterial production, primary production, microbial abundance, taxonomic and genetic diversity. In line with the debate over to whether the oligotrophic ocean acts as a $\mathrm{CO}_{2}$ sink or $\mathrm{CO}_{2}$ source to the atmosphere, efforts including empirical, theoretical and modeling approaches would help provide data to effectively improve knowledge about the SASG and support more accurate predictions in a changing global ocean.

\section{CONCLUSIONS}

In light of the exponential rate of progress in marine microbial ecology in the last few decades, our attempt to address the state of the art on the South Atlantic Subtropical Gyre encouraged us to also explore the dynamics of conceptual and methodological advances related to carbon flows and the role of oligotrophic gyres in the global biogeochemical cycles. In this context, the production of a timeline and compilation of publications in a historical perspective allowed us to summarize the main conceptual and methodological milestones that led to the current high level of understanding of the key oceanic processes with regard to microbial communities and the biological carbon pump. Furthermore, our overview of microbial ecology in oligotrophic open ocean basins allowed us to reinforce that better knowledge of subtropical oligotrophic gyres is a central task to determine the magnitude and variability of carbon 
exported from the surface to the deep ocean, as well as the exchange $\mathrm{CO}_{2}$ between the atmosphere and the ocean.

In turn, our compilation of publications on marine microbial ecology in SASG helped to highlight that the oligotrophic SAO is still among the least known oceanic provinces. Despite growing research efforts in this region over the past two decades, the lack of knowledge about the metabolic state, the main drivers of biogeographic patterns and taxonomic composition, together with undersampling, have hampered efforts to effectively improve knowledge of this region.

Ultimately, our metadata analysis helped reveal biogeographic patterns of microbial communities in different areas of oligotrophic SAO, highlighting the relative importance of different local vs. allochthonous sources of organic matter for the coupling between phytoplankton and heterotrophic bacteria in this region, suggesting that SASG is predominantly autotrophic, acting as a $\mathrm{CO}_{2}$ sink.

Since previous studies have pointed to temperature as a key variable for shaping microbial structure in open ocean basins, current evidence of climate change and ocean warming from the last IPCC reports challenges the idea that a shift in the balance between autotrophic production and heterotrophic consumption in SASG would favor a positive feedback for increasing atmospheric $\mathrm{CO}_{2}$.

Therefore, research efforts concerning marine $\mathrm{mi}-$ crobial ecology in open ocean basins and subtropical oligotrophic gyres have assumed new importance in predicting the implications of global change for the microbial plankton community, carbon flow in the pelagic system, and $\mathrm{CO}_{2}$ exchanges between the ocean and atmosphere.

\section{ACKNOWLEDGMENTS}

This paper was written as a result of a graduate course (Marine Plankton Secondary Production; Oceanographic Institute, University of São Paulo). LRF, SBP, LSM, GMV and CG thank to CNPq (National Council for Scientific and Technological Development) and CAPES (Coordination for the Improvement of Higher Education Personnel - Brazil) for their Master and Doctorate fellowships. RML is a CNPq fellow (310642/2017-5). The authors thank Janet Reid for the English review, as well as the anonymous reviewers for their careful reading of our manuscript and their many insightful comments and suggestions. The authors are grateful to the researchers who performed excellent work previously and made this review possible through papers publications and data availability.

\section{AUTHOR CONTRIBUTIONS}

L.R.F.: Data curation, Visualization, Writing - original draft, Writing - review \& editing;

S.B.P.: Data curation, Writing - original draft; Statistical analyses

L.S.M., G.M., C.G.: Data curation

R.M.L.: Conceptualization, Supervision, Writing review \& editing;

C.N.S.: Conceptualization, Supervision, Writing review \& editing.

\section{REFERENCES}

ALLEN, R., HOFFMANN, L. J., LAW, C. S. \& SUMMERFIELD, T. C. 2020. Subtle bacterioplankton community responses to elevated $\mathrm{CO}_{2}$ and warming in the oligotrophic South Pacific gyre. Environmental Microbiology Reports, 12(4), 377-386.

ALVES JUNIOR, N., MEIRELLES, P. M., SANTOS, E. O., DUTILH, B., SILVA, G. G. Z., PARANHOS, R., REZENDE, C. E., LIDA, T., MOURA, R.L., KRÜGER, R. H., SAWABE, T. \& THOMPSON, F. 2015. Microbial community diversity and physical-chemical features of the Southwestern Atlantic Ocean. Archives of Microbiology, 197(2), 165-179.

ANDRADE, L., GONZALEZ, A. M., REZENDE, C. E., SUZUKI, M., VALENTIN, J. L. \& PARANHOS, R. 2007. Distribution of HNA and LNA bacterial groups in the Southwest Atlantic Ocean. Brazilian Journal of Microbiology, 38(2), 330-336.

ANDRADE, L., GONZALEZ, A. M., VALENTIN, J. L. \& PARANHOS, R. 2004. Bacterial abundance and production in the southwest Atlantic Ocean. Hydrobiologia, 511(1-3), 103-111.

ARÍSTEGUI, J. \& HARRISON, W. G. 2002. Decoupling of primary production and community respiration in the ocean: implications for regional carbon studies. Aquatic Microbial Ecology, 29(2), 199-209.

AZAM, F., FENCHEL, J. T., FIELD, J. G., GRAY, S., MEYER-REIL, L. A. \& THINGSTAD, T. F. 1983. The ecological role of water-column microbes in the sea. Marine Ecology Progress Series, 10, 257-263.

AZAM, F. \& MALFATTI, F. 2007. Microbial structuring of marine ecosystems. Nature Reviews Microbiology, 5(10), 782-791.

BERGO, N. M., SIGNORI, C. N., AMADO, A. M., BRANDINI, F. P. \& PELLIZARI, V. H. 2017. The partitioning of carbon biomass among the pico- and nano-plankton community in the South Brazilian Bight during a strong summer intrusion of South Atlantic Central Water. Frontiers in Marine Science, 4, 238.

BILLER, S. J., BERUBE, P. M., DOOLEY, K., WILLIAMS, M., SATINSKY, B. M., KACKL T., HOGLE, S. L., COE, A., BERGAUER, K., BOUMAN, H. A., BROWING, T. J., CORTE, D., HASSLER, C., HULSTON, D., JACQUOT, J. E., MASS, E. W., REINTHALER, T., SINTES, E., YOKOKAWA T. \& CHISHOLM, S.W. 2018. Marine microbial metagenomes sampled across space and time. Scientific Data, 5(1), 1-7. 
BRANDINI, F. P., NOGUEIRA JUNIOR, M., SIMIÃO, M., CODINA, J. C. U. \& NOERNBERG, M. A. 2014. Deep chlorophyll maximum and plankton community response to oceanic bottom intrusions on the continental shelf in the South Brazilian Bight. Continental Shelf Research, 89, 61-75. Deep chlorophyll maximum and plankton community response to oceanic bottom intrusions on the continental shelf in the South Brazilian Bight. Continental Shelf Research, 89, 61-75.

BRIX, H., GRUBER, N., KARL, D. M. \& BATES, N. R. 2006. On the relationships between primary, net community, and export production in subtropical gyres. Deep Sea Research Part II: Topical Studies in Oceanography, 53(5-7), 698-717.

BRUSONI, S. \& GEUNA, A. 2003. An international comparison of sectoral knowledge bases: Persistence and integration in the pharmaceutical industry. Research Policy, 32(10), 1897-1912.

CAMPBELL, L., NOLLA, H. A. \& VAULOT, D. 1994. The importance of Prochlorococcus to community structure in the central North Pacific Ocean. Limnology and Oceanography, 39(4), 954-961.

CASTRO, B. M., BRANDINI, F. P., PIRES-VANIN, A. M. S. \& MIRANDA, L. B. 2006. Multidisciplinary oceanographic processes on the Western Atlantic continental shelf between $4^{\circ} \mathrm{N}$ and $34^{\circ} \mathrm{S}$. In: ALLAN, R. R. \& KENNETH B. (eds.). The Sea. Cambridge: Harvard University Press, pp. 209-251.

CHISHOLM, S. W., OLSON R. J. \& YENTSCH C. M. 1988. Flow cytometry in oceanography: Status and prospects. Eos, Transactions of the American Geophysical Union, 69, 562-572.

CHO, B. C. \& AZAM, F. 1988. Major role of bacteria in biogeochemical fluxes in the oceans' interior. Nature, 332, 441-443.

CHO, B. C. \& AZAM, F. 1990. Biogeochemical significance of bacterial biomass in the ocean's euphotic zone. Marine Ecology Progress Series, 63(2), 253-259.

COLE, J. J., FINDLAY, S. \& PACE, M. L. 1988. Bacterial production in fresh and saltwater ecosystems: a cross-system overview. Marine Ecology Progress Series, 43(1), 1-10.

COUTINHO, F. H., VON MEIJENFELDT, F. A. B., WALTER, J. M., HARO-MORENO, J. M., LOPÉZ-PÉREZ, M., VAN VERK, M. C., THOMPSON, C. C., COSENZA, C. A. N., APPOLINARIO, C. L., PARANHOS, R., CABRAL, A., DUTILH, B. E. \& THOMPSON, F. L. 2021. Ecogenomics and metabolic potential of the South Atlantic Ocean microbiome. Science of the Total Environment, 765, 142758.

DEL GIORGIO, P. A. \& COLE, J. J. 1998. Bacterial growth efficiency in natural aquatic systems. Annual Review of Ecology and Systematics, 29, 503-541.

DEL GIORGIO, P. A., COLE, J. J. \& CIMBLERIS, A. 1997. Respiration rates in bacteria exceed phytoplankton production in unproductive aquatic systems. Nature, 385(6612), 148-151.

DELONG, E. F. 1992. Archaea in coastal marine environments. Proceedings of the National Academy of Sciences of the U.S.A., 89(12), 5685-5689.

DELONG, E. F., PRESTON, C. M., MINCER, T., RICH, V., HALLAM, S. J., FRIGAARD, N. U. \& CHISHOLM, S. W. 2006. Community genomics among stratified microbial assemblages in the ocean's interior. Science, 311(5760)، 496-503.

DENTENER, F., KINNE, S., BOND, T., BOUCHER, O., COFALA, J., GENEROSO, S., GINOUX, P., GONG, S., HOELZEMANN, J. J., ITO, A., MARELLI, L., PENNER, J. E., PUTAUD, J. P., SCHULZ, M., VAN DER WERF, G. R. \& WILSON, J. 2006. Emissions of primary aerosol and precursor gases in the years 2000 and 1750 prescribed data-sets for AeroCom. Atmospheric Chemistry and Physics, 6(12), 4321-4344,
DUARTE, C. M. 2015. Seafaring in the 21st century: the Malaspina 2010 circumnavigation expedition. Limnology and Oceanography Bulletin, 24(1), 11-14.

DUARTE, C. M., LOSADA, I. J., HENDRIKS, I. E., MAZARRASA, I. \& MARBÀ, N. 2013. The role of coastal plant communities for climate change mitigation and adaptation. Nature Climate Change, 3(11), 961-968.

DUCE, R. A., LAROCHE, J., ALTIERI, K., ARRIGO, K. R., BAKER, A. R., CAPONE, D. G., CORNELL, S., DENTENER, F., GALLOWAY, J., GANESHRAM, R. S., GEIDER, R. J., JICHKELLS, T., KUYPERS, M. M., LANGLOIS, R., LISS, P. S., LIU, S. M., MIDDELBURG, J. J., MOORE, C. M., NICKOVIC, S., OSCHLIES, A., PEDERSON, T., PROSPERO, J., SCHILITZER, R., SEITZINGER, S., SORENSEN, L. L., UEMATSU, M., ULLOA, O., VOSS, M., WARD, B. \& ZAMORA, L. 2008. Impacts of atmospheric anthropogenic nitrogen on the open ocean. Science, 320(5878), 893-897.

DUCKLOW, H. W. \& KIRCHMAN, D. L. 1983. Bacterial dynamics and distribution during a spring diatom bloom in the Hudson River plume, USA. Journal of Plankton Research, 5(3), 333-355.

EVANS, C., GÓMEZ-PEREIRA, P. R., MARTIN, A. P., SCANLAN, D. J. \& ZUBKOV, M. V. 2015. Photoheterotrophy of bacterioplankton is ubiquitous in the surface oligotrophic ocean. Progress in Oceanography, 135, 139-145.

FALCÓN, L. I., NOGUEZ, A. M., ESPINOSA-ASUAR, L., EGUIARTE, L. E. \& SOUZA, V. 2008. Evidence of biogeography in surface ocean bacterioplankton assemblages. Marine Genomics, 1(2), 55-61.

FALKOWSKI, P. G. 2012. Ocean science: the power of plankton. Nature, 483(7387), S17-S20.

FALKOWSKI, P. G., FENCHEL, T. \& DELONG, E. F. 2008. The microbial engines that drive earth's biogeochemical Cycles. Science, 320(5879), 1034-1039.

FOGG, G. E. 1995. Some comments on picoplankton and its importance in the pelagic ecosystem. Aquatic Microbial Ecology, 9(1), 33-39.

FRAME, J. D. 1977. Mainstream research in Latin America and the Caribbean. Interciencia, 2(3), 143-148.

FUHRMAN, J. A. 1999. Marine viruses and their biogeochemical and ecological effects. Nature, 399(6736), 541-548.

FUHRMAN, J. A. \& AZAM, F. 1980. Bacterioplankton secondary production estimates for coastal waters of British Columbia, Antarctica, and California. Applied and Environmental Microbiology, 39(6), 1085-1095.

FUHRMAN, J. A. \& AZAM, F. 1982. Thymidine incorporation as a measure of heterotrophic bacterioplankton production in marine surface waters: evaluation and field results. Marine Biology, 66, 109-120.

FUHRMAN, J. A., EPPLEY, R. W., HAGSTROM, A. \& AZAM, F. 1985. Diel variations in bacterioplankton, phytoplankton, and related parameters in the Southern California Bight. Marine Ecology Progress Series, 27, 9-20.

FUHRMAN, J. A., SLEETER, T. D., CARLSON, C. A. \& PROCTOR, L. M. 1989. Dominance of bacterial biomass in the Sargasso Sea and its ecological implications. Marine Ecology Progress Series, 57, 207-217.

GARCÍA-MARTÍN, E. E., ARANGUREN-GASSIS, M., HARTMANN, M., ZUBKOV, M. V. \& SERRET, P. 2017. Contribution of bacterial respiration to plankton respiration from $50^{\circ} \mathrm{N}$ to $44^{\circ} \mathrm{S}$ in the Atlantic Ocean. Progress in Oceanography, 158, 99-108. 
GASOL, J. M. \& KIRCHMAN, D. L. 2018. Microbial ecology of the oceans. $3^{\text {rd }}$ ed. Hoboken: Wiley-Blackwell.

GASOL, J. M., PINHASSI, J., ALONSO-SÁEZ, L., DUCKLOW, H., HERNDL, G. J., KOBLÍZEK, M., LABRENZ, M., LU, H., MORÁN, X. A. G., REINTHALER, T. \& SIMON, M. 2008. Towards a better understanding of microbial carbon flux in the sea. Aquatic Microbial Ecology, 53, 21-38.

GASOL, J. M., VÁZQUEZ-DOMÍNGUEZ, E., VAQUÉ, D., AGUSTÍ, S. \& DUARTE, C. M. 2009. Bacterial activity and diffusive nutrient supply in the oligotrophic Central Atlantic Ocean. Aquatic Microbial Ecology, 7(1), 1-12.

GIOVANNONI, S. J. 2017. SAR11 bacteria: the most abundant plankton in the oceans. Annual Review of Marine Science, 9, 231-255.

GIST, N., SERRET, P., WOODWARD, E. M. S., CHAMBERLAIN, K. \& ROBINSON, C. 2009. Seasonal and spatial variability in plankton production and respiration in the Subtropical Gyres of the Atlantic Ocean. Deep Sea Research Part II: Topical Studies in Oceanography, 56(15), 931-940.

GONZÁLEZ, N., ANADÓN, R. \& MARAÑÓN, E. 2002. Large-scale variability of planktonic net community metabolism in the Atlantic Ocean: importance of temporal changes in oligotrophic subtropical waters. Marine Ecology Progress Series, 233, 21-30.

GROSSART, H. P., MASSANA, R., MCMAHON, K. D. \& WALSH, D. A. 2020. Linking metagenomics to aquatic microbial ecology and biogeochemical cycles. Limnology and Oceanography, 65(Suppl 1), S2-S20.

HAMMER, $\varnothing$, HARPER, D. A. T. \& RYAN, P. D. 2001. PAST: paleontological statistics software package for education and data analysis. Palaeontologia Electronica, 4(1), 1-9.

HILL, K. L., RINTOUL, S. R., RIDGWAY, K. R. \& OKE, P. R. 2011. Decadal changes in the South Pacific western boundary current system revealed in observations and ocean state estimates. Journal of Geophysical Research: Oceans, 116(C1), C01009.

HOBBIE, J. E. \& COLE, J. J. 1984. Response of a detrital food web to eutrophication. Bulletin of Marine Science, 35(3), 357-363.

HOBBIE, J. E., DALEY, R. J. \& JASPER, S. 1977. Use of nuclepore filters for counting bacteria by fluorescence microscopy. Applied and Environmental Microbiology, 33(5), 1225-1228.

HOPPE, H. G., BREITHAUPT, P., WALTHER, K., KOPPE, R., BLECK, S., SOMMER, U. \& JÜRGENS, K. 2008. Climate warming in winter affects the coupling between phytoplankton and bacteria during the spring bloom: a mesocosm study. Aquatic Microbial Ecology, 51(2), 105-115.

HOPPE, H. G., GOCKE, K., KOPPE, R. \& BEGLER, C. 2002. Bacterial growth and primary production along a north-south transect of the Atlantic Ocean. Nature, 416(6877), 168-171.

HOPPE, H. G., GOCKE, K., KOPPE, R. \& KRAUS, G. 2006. Changing bacterioplankton growth characteristics on a large spatial scale: oligotrophic versus mesotrophic ocean. Marine Ecology Progress Series, 323, 21-33.

HU, Z. Z., KUMAR, A., JHA, B., ZHU, J. \& HUANG, B. 2017. Persistence and predictions of the remarkable warm anomaly in the northeastern Pacific Ocean during 2014-16. Journal of Climate, 30(2), 689-702.

HUETE-STAUFFER, T. M., ARANDIA-GOROSTIDI, N., ALONSO-SÁEZ, L. \& MORÁN, X. A. G. 2016. Experimental warming decreases the average size and nucleic acid content of marine bacterial communities. Frontiers in Microbiology, 7, 730.
HUTCHINS, D. A. \& FU, F. 2017. Microorganisms and ocean global change. Nature Microbiology, 2(6), 17058.

IPCC (Intergovernmental Panel on Climate Change). STOCKER, T. F., QIN, D., PLATTNER, G., TIGNOR, M., ALLEN, S. K., BOSCHUNG, J., NAUEL, A., XIA, Y., BEX, V. \& MIDGLEY, P. M. (eds.). Climate change 2013: the physical science basis. Cambridge: Cambridge University Press, pp. 1535.

JIAO, N. \& AZAM, F. 2011. Microbial carbon pump and its significance for carbon sequestration in the ocean. Microbial Carbon Pump in the Ocean, 10, 43-45.

JIAO, N., HERNDL, G. J., HANSELL, D. A., BENNER, R., KATTNER, G., WlLHELM, S. W. \& AZAM, F. 2010. Microbial production of recalcitrant dissolved organic matter: long-term carbon storage in the global ocean. Nature Reviews Microbiology, 8(8), 593-599.

JIAO, N., ROBINSON, C., AZAM, F., THOMAS, H., BALTAR, F., DANG, H., HARDMAN-MOUNTFORD, N. J., JOHNSON, M., KIRCHMAN, D. L., KOCH, B. P., LEGENDRE, L., LI, C., LIU, J., LUO, T., LUO, Y. W., MITRA, A., ROMANOU, A., TANG, K., WANG, X., ZHANG, C. \& ZHANG, R. 2014. Mechanisms of microbial carbon sequestration in the ocean-future research directions. Biogeosciences, 11(19), 5285-5306.

KARL, D. M. 2007. Microbial oceanography: paradigms, processes and promise. Nature Reviews Microbiology, 5(10), 759-769.

KIRCHMAN, D. L. \& HOCH, M. P. 1988. Bacterial production in the Delaware Bay estuary estimated from thymidine and leucine incorporation rates. Marine Ecology Progress Series, 45(1), 169-178.

KIRCHMAN, D. L., K'NEES, E. \& HODSON, R. 1985. Leucine incorporation and its potential as a measure of protein synthesis by bacteria in natural aquatic systems. Applied and Environmental Microbiology, 49(3), 599-607.

KIRCHMAN, D. L., KEIL, R. G. \&WHEELER, P. A. 1989. The effect of amino acids on ammonium utilization and regeneration by heterotrophic bacteria in the subarctic Pacific. Deep Sea Research Part A. Oceanographic Research Papers, 36(11), 1763-1776.

KUMARI, L. 2006. Trends in synthetic organic chemistry research. Cross-country comparison of activity index. Scientometrics, 67(3), 467-476.

LARA, E., ARRIETA, J. M., GARCIA-ZARANDONA, I., BORAS, J. A., DUARTE, C. M., AGUSTÍ, S., WASSMAN, P. \& VAQUÉ, D. 2013. Experimental evaluation of the warming effect on viral, bacterial and protistan communities in two contrasting Arctic systems. Aquatic Microbial Ecology, 70(1), 17-32.

LÊ, S., JOSSE, J. \& HUSSON, F. 2008. FactoMineR: a package for multivariate analysis. Journal of Statistical Software, 25(1), 1-18.

LEGENDRE, L., RIVKIN, R. B., WEINBAUER, M. G., GUIDI, L. \& UITZ, J. 2015. The microbial carbon pump concept: Potential biogeochemical significance in the globally changing ocean. Progress in Oceanography, 134, 432-450.

LI, W. K. W., DICKIE, P. M., IRWIN, B. D. \& WOOD, A. M. 1992. Biomass of bacteria, cyanobacteria, prochlorophytes and photosynthetic eukaryotes in the Sargasso Sea. Deep Sea Research Part A, Oceanographic Research Papers, 39(3-4), 501-519.

LOGARES, R., DEUTSCHMANN, I. M., JUNGER, P. C., GINER, C. R., KRABBERØD, A. K., SCHMIDT, T. S., RUBINAT-RIPOLL, L., MESTRE, M., SALAZAR, G., RUIZ-GONZÁLEZ, C., SEBASTIÁN, M., VARGAS, C., ACINAS, S. G., DUARTE, C. M., GASOL, J. M. \& MASSANA, R. 2020. Disentangling the mechanisms shaping the surface ocean microbiota. Microbiome, 8, 55 . 
LONGHURST, A. R. 2010. Ecological geography of the sea. Amsterdam: Academic Press.

LOUCA, S., PARFREY, L. W. \& DOEBELI, M. 2016. Decoupling function and taxonomy in the global ocean microbiome. Science, 353(6305), 1272-1277.

MALONE, T. C. \& DUCKLOW, H. W. 1990. Microbial biomass in the coastal plume of Chesapeake Bay: Phytoplankton-bacterioplankton relationships. Limnology and Oceanography, 35(2), 296-312.

MANRIQUE, J. M. \& JONES, L. R. 2017. Are ocean currents to slow to counteract SAR11 evolution? A next-generation sequencing, phylogeographic analysis. Molecular Phylogenetics and Evolution, 107, 324-337.

MARTÍNEZ-GARCÍA, S., FERNÁNDEZ, E., CALVO-DÍAZ, A., MARAÑÓN, E., MORÁN, X. A. G. \& TEIRA, E. 2010. Response of heterotrophic and autotrophic microbial plankton to inorganic and organic inputs along a latitudinal transect in the Atlantic Ocean. Biogeosciences, 7(5), 1701-1713.

MAZUECOS, I. P., ARÍSTEGUI, J., VÁZQUEZ-DOMÍNGUEZ, E., ORTEGA-RETUERTA, E., GASOL, J. M. \& RECHE, I. 2015. Temperature control of microbial respiration and growth efficiency in the mesopelagic zone of the South Atlantic and Indian Oceans. Deep Sea Research Part I: Oceanographic Research Papers, 95, 131-138.

MCCLAIN, C. R., SIGNORINI, S. R. \& CHRISTIAN, J. R. 2004. Subtropical gyre variability observed by ocean-color satellites. Deep Sea Research Part II: Topical Studies in Oceanography, 51(1-3), 281-301.

MCMANUS, G. B. \& PETERSON, W.T. 1988. Bacterioplankton production in the nearshore zone during upwelling off central Chile. Marine Ecology Progress Series, 43(1-2), 11-17.

METZLER, P. M., GLIBERT, P. M., GAETA, S. A. \& LUDLAM, J. M. 1997. New and regenerated production in the South Atlantic off Brazil. Deep Sea Research Part I: Oceanographic Research Papers, 44(3), 363-384.

MORÁN, X. A. G., ALONSO-SÁEZ, L., NOGUEIRA, E., DUCKLOW, H. W., GONZÁLEZ, N., LÓPEZ-URRUTIA, A., DÍAZ-PÉREZ, L., CALVO-DÍAZ, A., ARANDIA-GOROSTIDI, N. \& HUETE-STAUFFER, T. M. 2015. More, smaller bacteria in response to ocean's warming? Proceedings of the Royal Society B, 282(1810), 20150371.

MORRIS, R. M., FRAZAR, C. D. \& CARLSON, C. A. 2012. Basin-scale patterns in the abundance of SAR11 subclades, marine Actinobacteria (OM1), members of the Roseobacter clade and OCS116 in the South Atlantic. Environmental Microbiology, 14(5), 1133-1144.

MORRIS, R. M., NUNN, B. L., FRAZAR, C., GOODLETT, D. R., TING, Y. S. \& ROCAP, G. 2010. Comparative metaproteomics reveals ocean-scale shifts in microbial nutrient utilization and energy transduction. The ISME Journal, 4(5), 673-685.

MORRIS, R. M., RAPPÉ, M. S., CONNON, S. A., VERGIN, K. L., SIEBOLD, W. A., CARLSON, C. A. \& GIOVANNONI, S. J. 2002. SAR11 clade dominates ocean surface bacterioplankton communities. Nature, 420(6917), 806-810.

OKSANEN, J., BLANCHET, F. G., KINDT, R., LEGENDRE, P., MINCHIN, P. R., O'HARA, R. B., SIMPSON, G. L., SOLYMOS, P., HENRY, M., STEVENS, H., WAGNER, H. \& OKSANEN, M. J. 2013. Package 'vegan'. Community Ecology Package, 2(9), 1-295.

OLSON, R. J., ZETTLER, E. R., CHISHOLM, S. W. \& DUSENBERRY, J. A. 1991. Advances in oceanography through flow cytometry. In: DEMERS, S. (ed.). Particle analysis in oceanography. Berlin: NATO ASI Series, Series G, Ecological Sciences/Springer, pp. 351-399.
PALENIK, B., BRAHAMSHA, B., LARIMER, F. W., LAND, M., HAUSER, L., CHAIN, P., LAMERDIN, J., REGALA, W., ALLEN, E. E., MCCARREN, J., PAULSEN, I., DUFRESNE, A., PAQRTENSKY, F., WEBB, E. A. \& WATERBURY, J. 2003. The genome of a motile marine Synechococcus. Nature, 424(6952), 1037-1042.

PARTENSKY, F., HESS, W. R. \& VAULOT, D. 1999. Prochlorococcus, a marine photosynthetic prokaryote of global significance. Microbiology and Molecular Biology Reviews, 63(1), 106-127.

PERNICE, M. C., FORN, I., GOMES, A., LARA, E., ALONSO-SÁEZ, L., ARRIETA, J. M., GARCIA, F. D. C., HERNANDO-MORALES, V., MACKENZIE, R., MESTRE, M., SINTES, E., TEIRA, E., VALENCIA, J., VARELA, M. M., VAQUÉ, D., DUARTE, C., GASOL, J. M. \& MASSANA R. 2015. Global abundance of planktonic heterotrophic protists in the deep ocean. The ISME Journal, 9(3), 782-792.

POMEROY, L. R. 1974. The ocean's food web: a changing paradigm. BioScience, 24(9), 499-504.

POMEROY, L. R. \& DEIBEL, D. 1986. Temperature regulation of bacterial activity during the spring bloom in Newfoundland coastal waters, Science, 233(4761), 359-361.

POMEROY, L. R., WILLIAMS, P. J. L., AZAM, F. \& HOBBIE, J. E. 2007. The microbial loop. Oceanography, 20(2), 28-33.

PORTER, K. G. \& FEIG, Y. S. 1980. The use of DAPI for identifying and counting aquatic microflora. Limnology and Oceanography, 25(5), 943-948.

RIBEIRO, C. G., MARIE, D., SANTOS, A. L., BRANDINI, F. P. \& VAULOT, D. 2016. Estimating microbial populations by flow cytometry: comparison between instruments. Limnology and Oceanography, 14(11), 750-758.

RIBEIRO, C. G., SANTOS, A. L., MARIE, D., PELLIZARI, V. H., BRANDINI F. P. \& VAULOT, D. 2016. Pico and nanoplankton abundance and carbon stocks along the Brazilian Bight. PeerJ, 4, e2587.

RIVKIN, R. B. \& LEGENDRE, L. 2001. Biogenic carbon cycling in the upper ocean: effects of microbial respiration. Science, 291(5512), 2398-2400.

ROCAP, G., LARIMER, F. W., LAMERDIN, J., MALFATTI, S., CHAIN, P., AHLGREN, N. A., ARELLANO, A., COLEMAN, M., HAUSER, L., HESS, W. R., JOHNSON, Z. I., LANDA, M., LINDELL, D., POST, A. F., REGALA, W., SHAH, M., SHAW, S. L., STEGLICH, C., SULLIVAN, M. B., TING, C. S., TOLONEN, A., WEBB, E. A., ZINSER, E. R. \& CHISHOLM, S. W. 2003. Genome divergence in two Prochlorococcus ecotypes reflects oceanic niche differentiation. Nature, 424(6952), 1042-1047.

RUSCH, D. B., HALPERN, A. L., SUTTON, G., HEIDELBERG, K. B., WILLIAMSON, S., YOOSEPH, S. \& BEESON, K. 2007. The Sorcerer II global ocean sampling expedition: northwest Atlantic through eastern tropical Pacific. PLoS Biology, 5(3), e77.

SANZ-SÁEZ, I., SALAZAR, G., SÁNCHEZ, P., LARA, E., ROYO-LLONCH, M., SÀ, E. L., LUCENA, T., PUJALTE, M. J., VAQUÉ, D., DUARTE, C. M., GASOL, J. M., PEDRÓS-ALIÓ, C., SÁNCHEZ, O. \& ACINAS, S. G. 2020. Diversity and distribution of marine heterotrophic bacteria from a large culture collection. BMCMicrobiology, 20(1), 207.

SARMENTO, H., MONTOYA, J. M., VÁZQUEZ-DOMÍNGUEZ, E., VAQUÉ, D. \& GASOL, J. M. 2010. Warming effects on marine microbial food web processes: how far can we go when it comes to predictions? Philosophical Transactions of the Royal Society B: Biological Sciences, 365(1549), 2137-2149.

SCHATTENHOFER, M., FUCHS, B. M., AMANN, R., ZUBKOV, M. V., TARRAN, G. A. \& PERNTHALER, J. 2009. Latitudinal distribution of prokaryotic picoplankton populations in the Atlantic Ocean. Environmental Microbiology, 11(8), 2078-2093. 
SERRET, P., FERNÁNDEZ, E. \& ROBINSON, C. 2002. Biogeographic differences in the net ecosystem metabolism of the open ocean. Ecology, 83(11), 3225-3234.

SERRET, P., ROBINSON, C., ARANGUREN-GASSIS, M., GARCÍA-MARTÍN, E. E., GIST, N., KITIDIS, V., LOZANO, J., STEPHENS, J., HARRIS, C. \& THOMAS, R. 2015. Both respiration and photosynthesis determine the scaling of plankton metabolism in the oligotrophic ocean. Nature Communications, 6(1), 1-10.

SERRET, P., ROBINSON, C., FERNÁNDEZ, E., TEIRA, E. \& TILSTONE, G. 2001. Latitudinal variation of the balance between plankton photosynthesis and respiration in the eastern Atlantic Ocean. Limnology and Oceanography, 46(7), 1642-1652.

SIEBURTH, J. M., SMETACEK, V. \& LENZ, J. 1978. Pelagic ecosystem structure: heterotrophic compartments of the plankton and their relationship to plankton size fractions. Limnology and Oceanography, 23(6), 1256-1263.

SIGNORINI, S. R., FRANZ, B. A. \& MCCLAIN, C. R. 2015. Chlorophyll variability in the oligotrophic gyres: mechanisms, seasonality and trends. Frontiers in Marine Science, 2, 1.

SCHLITZER, R. 2020. Ocean data view (ODV) [online]. Available at: https://odv.awi.de [Accessed: 10 April 2021].

SUNAGAWA, S., ACINAS, S. G., BORK, P., BOWLER, C., EVEILLARD, D., GORSKY, G., GUIDI, L., IUDICONE, D., KARSENTI, E., LOMBARD, F., OGATA, H., PESANT, S., SULLIVAN, M. B., WINCKER P. \& OGATA, H. 2020. Tara Oceans: towards global ocean ecosystems biology. Nature Reviews Microbiology, 18(8), 428-445.

SUNAGAWA, S., COELHO, L. P., CHAFFRON, S., KULTIMA, J. R., LABADIE, K., SALAZAR, G., DJAHANSCHIRI, B., ZELLER, G., MENDE, D. R., ALBERTI, A., CORNEJO-CASTILLO, F. M., COSTEA, P. I., CRUAUD, C., D'OVIDIO, F., ENGELEN, S., FERRERA, I., GASOL, J. M., GUIDI, L., HILDEBRAND, F., KOKOSZKA, F., LEPOIVRE, C., LIMA-MENDEZ, G., POULAIN, J., POULOS, B. T., ROYO-LLONCH, M., SARMENTO, H., VIEIRA-SILVA, S., DIMIER, C., PICHERAL M., SEARSON, S., KANDELS-LEWIS, S., BOWLER, C., VARGAS, C., GORSKY, G., GRIMSLEY, N., HINGAMP, S., SPIECH, S., STEMMANN, L., SULLIVAN, M. B., WEISSENBACH, J., WINCKER, P., KARSENTI, E., RAES, J., ACINAS, S. G. \& BORK, P. 2015. Structure and function of the global ocean microbiome. Science, 348(6237), 1261359.

SUSINI-RIBEIRO, S. M., POMPEU, M., GAETA, S. A., SOUZA, J. S. \& MASUDA, L. S. 2013. Topographical and hydrographical impacts on the structure of microphytoplankton assemblages on the Abrolhos Bank region, Brazil. Continental Shelf Research, 70, 88-96.

SWAN, B. K., CHAFFIN, M. D., MARTINEZ-GARCIA, M., MORRISON, H. G., FIELD, E. K., POULTON, N. J., DASHIELL, E., MASLAND, P., HARRIS, C. C., SZYRBA, A., CHAIN, P. S. G., KOREN, S., WOYKE, T. \& STEPANAUSKAS, R. 2014. Genomic and metabolic diversity of Marine Group I Thaumarchaeota in the mesopelagic of two subtropical gyres. PloS One, 9(4), e95380.

TEIRA, E., MARTíNEZ-GARCÍA, S., CALVO-DÍAZ, A. \& MORÁN, X. A. G. 2010. Effects of inorganic and organic nutrient inputs on bacterioplankton community composition along a latitudinal transect in the Atlantic Ocean. Aquatic Microbial Ecology, 60(3), 299-313.

THOMAIDIS, N. S., GEORGIOU, C. A. \& CALOKERINOS, A. C. 2004. Analytical chemistry in Balkan and East Mediterranean countries during 1994-2001. Analytica Chimica Acta, 505(1), 3-8.
THOMPSON, L. R., SANDERS, J. G., MCDONALD, D., AMIR, A., LADAU, J., LOCEY, K. J., PRILL, R. J., TRIPATHI, A., GIBBONS, S. M., ACKERMAN, G., NAVAS-MOLINA, J. A., JANSSEN, S., KOPULOVA, E., VÁZQUEZ-BAEZA, Y, HAROON, M. F., MORTON, J. T., MIRARAB, S., XU, Z. Z., HAROON, M. F., KANBAR, J., ZHU, Q., SONG, S. J., KOSCIOLEK, T., BOKULICH, N. A., LEFLER, J., BRISLAWN, C. J., HUMPHREY, G., OWENS, S. M., HAMPTON-MARCELL, J., BERG-LYONS, D., MCKENZIE, V., FIERER, N., FUHRMAN, J. A., CLAUSET, A., STEVENS, R. L., SHADE, A., POLLARD, K. S., GOODWIN, K. D., JANSSON, J. K., GILBERT, J. A., KINGHT, R. \& NAVAS-MOLINA, J. A. 2017. A communal catalogue reveals Earth's multiscale microbial diversity. $\mathrm{Na}$ ture, 551(7681), 457-463.

TILSTONE, G. H., XIE, Y. Y., ROBINSON, C., SERRET, P., RAITSOS, D. E., POWELL, T., ARAGUREN-GASSIS, M., GARCIA-MARTIN, E. \& KITIDIS, V. 2015. Satellite estimates of net community production indicate predominance of net autotrophy in the Atlantic Ocean. Remote Sensing of Environment, 164, 254-269.

TULLY, B. J., GRAHAM, E. D. \& HEIDELBERG, J. F. 2018. The reconstruction of 2,631 draft metagenome-assembled genomes from the global oceans. Scientific Data, 5(1), 170203.

VÁZQUEZ-DOMÍNGUEZ, E., DUARTE, C. M., AGUSTÍ, S., JÜRGENS, K., VAQUÉ, D. \& GASOL, J. M. 2008. Microbial plankton abundance and heterotrophic activity across the Central Atlantic Ocean. Progress in Oceanography, 79(1), 83-94.

WATSON, S. W., NOVITSKY, T. J., QUINBY, H. L. \& VALOIS, F. W. 1977. Determination of bacterial number and biomass in the marine environment. Applied and Environmental Microbiology, 33(4), 940-947.

WESTBERRY, T. K., WILLIAMS, P. J. L. B. \& BEHRENFELD, M. J. 2012. Global net community production and the putative net heterotrophy of the oligotrophic oceans. Global Biogeochemical Cycles, 26(4), GB4019.

WHITMAN, W. B., COLEMAN D. C. \& WIEBE, W. J. 1998. Prokaryotes: the unseen majority. Proceedings of the National Academy of Sciences of the U.S.A., 95(12), 6578-6583.

WILLIAMS, P. J. B. 1981. Microbial contribution to overall marine plankton metabolism-direct measurements of respiration. Oceanologica Acta, 4(3), 359-364.

WILLIAMS, P. J. B. 1998. The balance of plankton respiration and photosynthesis in the open oceans. Nature, 394(6688), 55-57.

WILLIAMS, P. J. B., QUAY, P. D., WESTBERRY, T. K. \& BEHRENFELD, M. J. 2013. The oligotrophic ocean is autotrophic. Annual Review of Marine Science, 5, 535-549.

WOHLERS, J., ENGEL, A., ZÖLLNER, E., BREITHAUPT, P., JÜRGENS, K., HOPPE, H. G., SOMMER, U. \& RIEBESELL, U. 2009. Changes in biogenic carbon flow in response to sea surface warming. Proceedings of the National Academy of Sciences of the U.S.A., 106(17), 7067-7072.

WORDEN, A. Z., FOLLOWS, M. J., GIOVANNONI, S. J., WILKEN, S., ZIMMERMAN, A. E. \& KEELING, P. J. 2015. Environmental science. Rethinking the marine carbon cycle: factoring in the multifarious lifestyles of microbes. Science, 347(6223), 1257594.

YENTSCH, C. M., HORAN, P. K., MUIRHEAD, K., DORTCH, Q., HAUGEN, E., LEGENDRE, L., MURPHY, L. S., PERRY, M. J., PHINNEY, D. A., POMPONI, S. A., SPINRAD, R. W. \& WO, M. 1983. Flow cytometry and cell sorting: a technique for analysis and sorting of aquatic particles. Limnology and Oceanography, 28(6), 1275-1280. 
ZHANG, F., LIU, J., LI, Q., ZOU, L. \& ZHANG, Y. 2016. The research of typical microbial functional group reveals a new oceanic carbon sequestration mechanism - a case of innovative method promoting scientific discovery. Science China Earth Sciences, 59(3), 456-463.

ZHANG, Y., ZHAO, M., CUI, Q., FAN, W., QI, J., CHEN, Y., ZHANG, Y.Y., GAO, K., FAN, J. F., WANG, G. Y., YAN, C. L., LU, H. L., LUO, Z. L., ZHANG, Z. L., ZHENG, Q., XIAO, W. \& JIAO, N.Z. 2017. Processes of coastal ecosystem carbon sequestration and approaches for increasing carbon sink. Science China Earth Sciences, 60(5), 809-820.

ZUBKOV, M. V., SLEIGH, M. A. \& BURKILL, P. H. 2000. Assaying picoplankton distribution by flow cytometry of underway samples collected along a meridional transect across the Atlantic Ocean. Aquatic Microbial Ecology, 21(1), 13-20.
ZUBKOV, M. V., SLEIGH, M. A., BURKILL, P. H. \& LEAKEY, R. J. 2000a. Picoplankton community structure on the Atlantic Meridional Transect: a comparison between seasons. Progress in oceanography, 45(3-4), 369-386.

ZUBKOV, M. V., SLEIGH, M. A., BURKILL, P. H. \& LEAKEY, R. J. 2000b. Bacterial growth and grazing loss in contrasting areas of North and South Atlantic. Journal of Plankton Research, 22(4), 685-711.

ZUBKOV, M. V., SLEIGH, M. A., TARRAN, G. A., BURKILL, P. H. \& LEAKEY, R. J. 1998. Picoplanktonic community structure on an Atlantic transect from $50^{\circ} \mathrm{N}$ to $50^{\circ} \mathrm{S}$. Deep Sea Research Part I: Oceanographic Research Papers, 45(8), 1339-1355. 